\title{
Psychosocial Intervention
}

www.elsevier.es/psi

\section{Influence of health personnel's attitudes and knowledge in the detection and reporting of elder abuse: An exploratory systematic review}

\author{
Carmen Touza Garma \\ Departamento de Pedagogía y Didácticas Específicas, Universidad de las Islas Baleares, Spain
}

\section{A R T I C L E I N F O}

\section{Article history:}

Received 2 June 2016

Accepted 5 November 2016

Available online 28 December 2016

\section{Keywords:}

Elder abuse

Health professionals

Detection

Reporting

Exploratory systematic review

\begin{abstract}
A B S T R A C T
This article reviews the main results and conclusions of published studies concerning the influence of the knowledge and attitudes of health professionals in detecting and reporting elder abuse. Fifty-seven articles published in English or Spanish between 2000 and 2014 were analysed. The main findings and conclusions are presented around four themes: (1) the influence of definitions used by professionals in the detection and reporting of abuse; (2) the ability of knowledge and attitudes of professionals to act as barriers or facilitators of abuse detection and reporting; (3) the influence of the knowledge and attitudes of professionals in strategies for action taken in response to suspected abuse; and (4) training as a means to improve the competence of professionals to detect and report abuse. Results show the influence of knowledge and attitudes, but testing the theoretical models that integrate the relationship of these variables to other factors that affect decision processes and actions of health professionals is needed. Findings from such tests will facilitate the design of intervention strategies to increase the likelihood that health professionals will detect and report abuse.

(c) 2016 Colegio Oficial de Psicólogos de Madrid. Published by Elsevier España, S.L.U. This is an open access article under the CC BY-NC-ND license (http://creativecommons.org/licenses/by-nc-nd/4.0/).

\section{La influencia de las actitudes y de los conocimientos de los profesionales de la salud en la detección y notificación de los malos tratos a las personas mayores. Una revisión sistemática exploratoria}

\section{R E S U M E N}

Este artículo presenta una revisión de los principales resultados y conclusiones de los estudios sobre la influencia de los conocimientos y las actitudes de los profesionales de la salud en la detección y la notificación del maltrato a las personas mayores. Se analizaron 57 artículos publicados en inglés o en español entre los años 2000 y 2014. Los principales resultados y conclusiones encontrados se exponen en torno a 4 líneas temáticas: 1) la influencia de las definiciones utilizadas por los profesionales en la detección y la notificación; 2) el papel de los conocimientos y las actitudes de los profesionales como barreras o facilitadores de la detección y la notificación; 3) la influencia de los conocimientos y las actitudes de los profesionales en las estrategias de actuación ante la sospecha de maltrato, y 4) la formación como medio para mejorar la competencia de los profesionales para detectar y notificar. Los resultados de las investigaciones muestran la influencia de los conocimientos y las actitudes, pero sería necesario probar modelos teóricos que integrasen la relación de estas variables con otras que han demostrado influir en el proceso de decisión y en las actuaciones de los profesionales. Sus resultados facilitarían el diseño de estrategias de intervención para aumentar el número de casos detectados y notificados por los profesionales.

(c) 2016 Colegio Oficial de Psicólogos de Madrid. Publicado por Elsevier España, S.L.U. Este es un artículo Open Access bajo la licencia CC BY-NC-ND (http://creativecommons.org/licenses/by-nc-nd/ 
Elder abuse is a single or repeated act or lack of appropriate action that causes an older person harm or distress within any relationship where there is an expectation of trust (World Health Organization, 2002). Elder abuse represents a significant public health and social problem. Maltreatment of the elderly can produce serious consequences for their health and wellbeing, including reduced quality of life, psychological distress, loss of property and security, and increased morbidity and mortality. As the size of the aged population grows, the number of elder abuse cases is also likely to increase. In Europe, the proportion of people 65 years of age and older is predicted to grow from $14 \%$ in 2010 to $25 \%$ in 2050 (World Health Organization, 2011). The prevalence of elder abuse varies widely. A recent systematic review showed that in North and South America, the prevalence of elder abuse ranged from $10 \%$ in cognitively intact older adults to 47.3\% in older adults with dementia (Dong, 2015). Meanwhile, the European Report on Preventing Elder Maltreatment (World Health Organization, 2011) showed that the prevalence of maltreatment in community-dwelling elders was high (about 3\%) and might be higher (25\%) for older people with high support needs. According to this report, older people receiving formal care either at home or in care settings were more vulnerable to maltreatment, with an average rate of $11 \%$ in the European Union (World Health Organization, 2011).

There is a general agreement that health professionals, especially doctors and nurses, have an important role in detecting and reporting abuse due to the nature of their contacts and relationships with the older people. Physicians and nurses are best placed to recognise these cases since most elderly people trust them (Almogue, Weiss, Marcus, \& Beloosesky, 2010). These professionals are usually the first contacts of abuse victims may have with a medical or social service organisations or agencies and their ability to recognise the signs and symptoms of elder abuse is of utmost importance (Rinker, 2009). Because victims of elder abuse tend to be isolated, their interactions with physicians present critically important opportunities to recognise elder abuse and to intervene or refer the victims to appropriate providers (Lachs \& Pillemer, 2015). However, professionals have difficulty recognizing suspected cases of elder abuse, and the percentage of reported cases is very low even when professionals suspect abuse (Yaffe, Wolfson, \& Lithwick, 2009). Some studies have suggested that for every case of elder abuse reported, 23 go undetected (American Psychological Association, 2012). Despite mandated reporting laws that require health professionals to report elder abuse, health professionals have low rates of reporting.

Elder abuse has only recently been addressed in the medical literature (Kennedy, 2005). Little is known of how much the health professionals know and understand the problem (McCreadie, Bennett, Gilthorpe, Houghton, \& Tinker, 2000), and reasons for lack of reporting are understudied. Underreporting appears to be related to the fact that the perpetrators of abuse are usually family members or carers, and of equal importance is a general community lack of understanding and health professionals' lack of education in recognition of aged abuse (Joubert \& Posenelli, 2009). Professionals report that lack of confidence and knowledge regarding defining, diagnosing, and reporting abuse are important barriers to managing abuse effectively (Cooper, Selwood, \& Livingston, 2009). Professionals' knowledge and skills have been considered a clear deficit in detection, and the education of medical staff has been identified as the most effective way of improving the recognition of cases of abuse (Joubert \& Posenelli, 2009). Professionals' attitudes also seem to influence their decision to report. Reluctance to report abuse unless certain that it had occurred, empathy with the abuser (if another professional), fear of the consequences of reporting, dissatisfaction with the authorities' response to the reported abuse cases, and the lack of confidence in identifying or reporting geriatric victims of abuse or neglect have emerged as factors that can reduce reporting (Clark-Daniels, Daniels, \& Baumhover, 1990; Jones, Veenstra, Seamon, \& Krohmer, 1997).

We hypothesised that the knowledge and attitudes of health professionals regarding abuse could be factors that influence their ability to detect and report elder abuse, as well as their decisions and actions in response to suspected abuse. The final decision could be the result of an overall assessment of the case that includes very different factors. Knowing the most relevant knowledge and attitudes in the decision-making process and how they interact with other variables may provide guidance to implement interventions that medical staff could take to improve abuse detection and reporting. For these reasons, we decided to conduct an exploratory review on this issue.

The purpose of this exploratory review was to develop an overview of the main results and conclusions of published studies concerning the influence of the knowledge and attitudes of health professionals in detecting and reporting elder abuse. The main question that guided this review was: What are the main findings and conclusions of articles published between 2000 and 2014 on the relationship between the attitudes, knowledge, and actions of health professionals in detecting and reporting cases of domestic and institutional elder abuse? In our literature search, two systematic reviews were found that analysed studies on the influence of the knowledge of professionals in detecting and reporting abuse cases and the factors that influence decision making (Cooper et al., 2009; Killick \& Taylor, 2009).

Cooper et al. (2009) conducted a systematic review to analyse health and social care professionals' knowledge of elder abuse, their ability to detect it, and their willingness to report it. They also examined characteristics of staff and organisations that were associated with more abuse being reported and any interventions designed to increase these outcomes. This review included original research articles reporting quantitative data, and the search was made in PubMed and Web of Science databases in November 2008.

The review conducted by Killick and Taylor (2009) sought to identify research material relating to older people living in the community who were subjected to abuse by an informal caregiver. Their purpose was to analyse the factors that influence professional decision making at the point of first referral. Eight databases were used in the search process: Ageinfo, ASSIA, CINAHL, Google Scholar, Medline, Psychinfo, Social Care Online, SSA, and SSCI. Inclusion criteria referred to English language, 1995-2006 inclusive, and empirical research design.

The purpose of the review presented here is different from the aims set by the previous two reviews. Although the three reviews analyse variables that influence the detection and reporting of situations of abuse, this review focuses specifically on the influence of attitudes and knowledge of health professionals. The range of material that was considered was also different. This review included more recent publications and covered databases listing publications in English or Spanish. It incorporated data from both qualitative and quantitative studies within the same review, as well as theoretical essays. Studies about people living in hospitals or nursing homes and abuse by paid staff or caregivers were not excluded.

The results of this exploratory review may complement and extend the results of the previous two reviews. They can provide valuable information to design research and interventions that increase rates of detecting and reporting elder abuse, a prevalent and growing social problem with significant consequences on victims' health and wellbeing. 


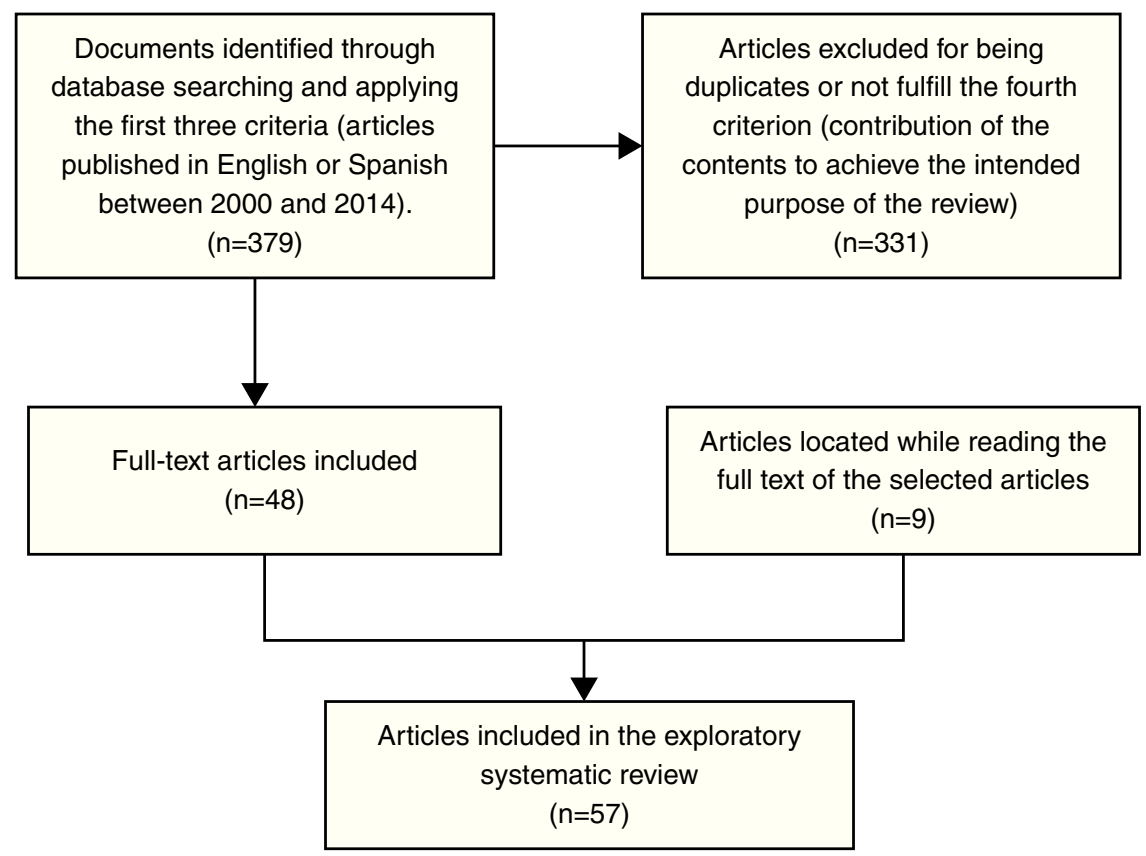

Fig. 1. Overview of article selection process.

\section{Method}

This exploratory review was conducted according to the described phases for conducting exploratory reviews, with the exception of an optional consultation (Arksey \& O'Malley, 2005; Armstrong, Hall, Doyle, \& Waters, 2011). The search was conducted in the following databases: PubMed, CINAHL, Cochrane Library Plus, Latin American and Caribbean Literature in Health Sciences (LILACS), Abstracts in Social Gerontology, PsycINFO, PsycARTICLES, Violence \& Abuse Abstracts, Family Studies Abstracts, Academic Search Premier, E-Journals, Spanish Medical Index (IME)-Biomedicina, Spanish Bibliographic Index in Health Sciences (IBECS), and ISOC-Social Science and Humanities. The English search terms used were the following: elder abuse, health personnel, health staff, health workers, perception, beliefs, attitudes, perspective, knowledge, practice. In Spanish, the following terms were applied: violencia, maltrato, malos tratos, mayor, anciano, tercera edad, viejo, vejez, profesional sanitario, salud, enfermera, médico, atención, práctica, intervención, conocimientos, creencias, actitudes, percepciones, perspectiva. Many of these terms were truncated and combined using Boolean operators. The searches were conducted following the parameters of each database, in the title, in the abstract, and in the descriptors.

The inclusion/exclusion criteria were the following: (1) type of publication: articles; (2) publication period: from 2000 to 2014; (3) language of publication: English or Spanish; and (4) contribution of the contents to achieve the intended purpose of the review. Study quality was not used as an exclusion criterion in the selection. Unlike systematic reviews, exploratory reviews often do not make exclusions based on quality (Armstrong et al., 2011), because the priority is the contribution made in the review synthesis.

Fig. 1 shows the article selection process. Using the search terms previously stated and applying the first three criteria, 379 articles were obtained. After removing duplicate articles and those that did not meet the fourth criterion, 48 papers were selected for further analysis. While reading the full text of the selected articles, nine other publications were identified that met the inclusion criteria and were also incorporated in the review.
Therefore, the total number of articles reviewed in this study was 57.

\section{Results}

Table 1 provides information about the articles assessed in this review.

As shown in Table 2, most of the reviewed articles consisted of primary investigations, two of which (Richardson, Kitchen, \& Livingston, 2002; Teresi et al., 2013) used randomised trials to test the effects of training programmes. Two articles analysed systematic reviews (Cooper et al., 2009; Killick \& Taylor, 2009). One (Cooper et al., 2009) incorporated a meta-analysis. The other documents were theoretical essays. Most of the investigations collected information through questionnaires. Interviews and focus groups were approaches that were also widely used. Several studies combined one or more of these techniques. Countries with a higher percentage of investigations were the United States, Australia, Israel, and the United Kingdom.

The main findings and conclusions of the analysed articles were classified around four themes: (1) the influence of definitions used by professionals for detecting and reporting elder abuse cases; (2) the ability of knowledge and attitudes of professionals to act as barriers or facilitators of detecting and reporting of abuse; (3) the influence of the knowledge and attitudes of professionals in strategies for action taken in response to suspected abuse; and (4) training as a means to improve the competence of professionals to detect and report elder abuse. The first thematic section focuses on the analysis of abuse definitions and the type of information on which professionals base their decisions. The second section presents the results of studies on factors that can facilitate or obstruct abuse detection and reporting, with knowledge and attitudes of health professionals being among the most studied factors. The third thematic section considers results of research on how knowledge and attitudes of professionals can influence the strategies of action to respond to suspected abuse. The fourth main theme focuses on the importance of training programmes to promote abuse detection and reporting to improve the knowledge and the attitudes of professionals towards abuse. 
Table 1

\begin{tabular}{|c|c|c|c|c|c|c|}
\hline $\begin{array}{l}\text { Authors and } \\
\text { publication date }\end{array}$ & Country & Type of study & Sample & $\begin{array}{l}\text { Information } \\
\text { gathering } \\
\text { techniques }\end{array}$ & Analysed variables & Main results \\
\hline $\begin{array}{l}\text { Ahern and } \\
\text { McDonald (2002) }\end{array}$ & Australia & Descriptive & $\begin{array}{l}\text { Registered nurses } \\
(n=95)\end{array}$ & Questionnaire & $\begin{array}{l}\text { Beliefs related to } \\
\text { whistleblowing, } \\
\text { patient advocacy } \\
\text { and traditional } \\
\text { roles of nursing }\end{array}$ & $\begin{array}{l}\text { Whistleblowers supported the beliefs inherent in patient } \\
\text { advocacy; nonwhistleblowers retained a belief in the } \\
\text { traditional role of nursing }\end{array}$ \\
\hline All (1994) & & $\begin{array}{l}\text { Theoretical } \\
\text { essay }\end{array}$ & & & & \\
\hline $\begin{array}{l}\text { Almogue et al. } \\
\text { (2010) }\end{array}$ & Israel & Descriptive & $\begin{array}{l}\text { Physicians and } \\
\text { nurses working in } \\
\text { the internal and } \\
\text { geriatric services } \\
\text { of a hospital and } \\
\text { long-term facilities } \\
(n=157)\end{array}$ & Questionnaire & $\begin{array}{l}\text { Level of general } \\
\text { knowledge of elder } \\
\text { abuse; level of } \\
\text { knowledge of } \\
\text { protocols and laws; } \\
\text { attitudes towards } \\
\text { elder abuse; } \\
\text { willingness to } \\
\text { report suspected } \\
\text { cases }\end{array}$ & $\begin{array}{l}\text { Participants had a low level of knowledge of elder abuse } \\
\text { issues, the relevant laws and regulations. No significant } \\
\text { differences relating to the knowledge of elder abuse were } \\
\text { found between nurses and physicians, nor between general } \\
\text { and geriatric hospital employees. Both physicians and nurses } \\
\text { tended to have neutral attitudes. Employees of geriatric } \\
\text { hospitals had better attitudes than general hospital workers. } \\
\text { The unwillingness to get legally involved had been the main } \\
\text { reason of not reporting suspected cases }\end{array}$ \\
\hline Bomba (2006) & & $\begin{array}{l}\text { Theoretical } \\
\text { essay }\end{array}$ & & & & \\
\hline Bond (2004) & & $\begin{array}{l}\text { Theoretical } \\
\text { essay }\end{array}$ & & & & \\
\hline Bover et al. (2003) & & $\begin{array}{l}\text { Theoretical } \\
\text { essay }\end{array}$ & & & & \\
\hline $\begin{array}{l}\text { Bužgová and } \\
\text { Ivanová (2009) }\end{array}$ & Czech Republic & Descriptive & $\begin{array}{l}\text { Residents and } \\
\text { employees of } \\
\text { residential homes, } \\
\text { and managers } \\
(n=48) ; \\
\text { complaints about } \\
\text { elder abuse }(n=11)\end{array}$ & $\begin{array}{l}\text { Interview and } \\
\text { analysis of } \\
\text { complaints } \\
\text { about } \\
\text { employees }\end{array}$ & $\begin{array}{l}\text { Employees' and } \\
\text { residents' lived } \\
\text { experiences } \\
\text { of elder abuse }\end{array}$ & $\begin{array}{l}\text { Two main dimensions of the examined phenomenon were } \\
\text { identified: forms of elder abuse (rights violation, financial } \\
\text { abuse, psychological abuse, physical abuse and neglect) } \\
\text { and causes of elder abuse (institution, employee and client } \\
\text { characteristics) }\end{array}$ \\
\hline Caciula et al. (2010) & Romania & Descriptive & $\begin{array}{l}\text { Care workers } \\
\text { and clients of a } \\
\text { non-government } \\
\text { home care } \\
\text { organisation } \\
(n=114)\end{array}$ & Questionnaire & $\begin{array}{l}\text { Identification of } \\
\text { elder abuse and } \\
\text { detection of elder } \\
\text { abuse at work }\end{array}$ & $\begin{array}{l}\text { Of the professionals, } 11.4 \% \text { had encountered a case of elder } \\
\text { abuse, } 5.7 \% \text { in the last year. No staff and only one older person } \\
\text { correctly identified all abusive strategies. Staff with more } \\
\text { professional caregiving experience recognised fewer abusive } \\
\text { strategies }\end{array}$ \\
\hline $\begin{array}{l}\text { Cohen and } \\
\text { Shinan-Altman } \\
\text { (2011) }\end{array}$ & Israel & Descriptive & $\begin{array}{l}\text { Nursing aides from } \\
\text { nursing homes } \\
(n=188)\end{array}$ & Questionnaire & $\begin{array}{l}\text { Work stressors, } \\
\text { burnout (emotional } \\
\text { exhaustion and } \\
\text { depersonalization), } \\
\text { attitudes to elder } \\
\text { abuse, } \\
\text { demographic and } \\
\text { work-related } \\
\text { variables }\end{array}$ & $\begin{array}{l}\text { New immigrant nursing aides reported a higher tendency to } \\
\text { condone abusive behaviours than did veteran nursing aides. } \\
\text { Twenty-three per cent of the variance in attitudes was } \\
\text { explained by group, demographics, work stressors and } \\
\text { burnout. Greater condoning of elder abuse was associated with } \\
\text { belonging to the new immigrant group, being unmarried and } \\
\text { reporting higher work stressors. An interaction effect of work } \\
\text { stressors } \times \text { group was found. Burnout was correlated with } \\
\text { greater condoning of elder abuse, but this association was not } \\
\text { significant when the other variables were controlled }\end{array}$ \\
\hline
\end{tabular}


Table

(Continued)

\begin{tabular}{|c|c|c|c|c|c|c|}
\hline $\begin{array}{l}\text { Authors and } \\
\text { publication date }\end{array}$ & Country & Type of study & Sample & $\begin{array}{l}\text { Information } \\
\text { gathering } \\
\text { techniques }\end{array}$ & Analysed variables & Main results \\
\hline Coma et al., 2007 & Spain & Descriptive & $\begin{array}{l}\text { Primary care } \\
\text { doctors and nurses } \\
(n=27)\end{array}$ & Focus groups & $\begin{array}{l}\text { Definition, } \\
\text { detection, risk } \\
\text { factors, and } \\
\text { management } \\
\text { of elder abuse }\end{array}$ & $\begin{array}{l}\text { The most frequent types of abuse were psychological and } \\
\text { financial. Dysfunctional families, stressed and under-trained } \\
\text { caregivers, and elder hostility were important risk factors. The } \\
\text { profile of the abuser was associated with mental disorders, } \\
\text { drug addiction and prior family violence in physical and } \\
\text { financial abuse, but no clear profile was identified for neglect } \\
\text { and abandonment. Detection was fruitless because social and } \\
\text { health resources were insufficient and limited intervention. } \\
\text { Education, monitoring and counselling of health professionals } \\
\text { were needed to intervene effectively }\end{array}$ \\
\hline Conry (2009) & & $\begin{array}{l}\text { Theoretical } \\
\text { essay }\end{array}$ & & & & \\
\hline Cooper et al. (2013) & $\begin{array}{l}\text { United } \\
\text { Kingdom }\end{array}$ & Descriptive & $\begin{array}{l}\text { Care workers from } \\
\text { care homes }(n=36)\end{array}$ & Focus groups & $\begin{array}{l}\text { Witnessed or } \\
\text { perpetrated abuse }\end{array}$ & $\begin{array}{l}\text { Participants reported that situations with potentially abusive } \\
\text { consequences were a common occurrence, but deliberate } \\
\text { abuse was rare. Behaviours witnessed could mostly be divided } \\
\text { into three categories: (1) situations which the care workers } \\
\text { thought were due to insufficient resources or competing } \\
\text { demands; (2) instances when staff acted in potentially abusive } \\
\text { ways, which they judged better for residents than alternatives; } \\
\text { (3) situations related to institutional practices. The likelihood } \\
\text { of abusive situations was determined by factors related to the } \\
\text { institutions, the care workers, and the residents }\end{array}$ \\
\hline Cooper et al. (2012) & $\begin{array}{l}\text { United } \\
\text { Kingdom }\end{array}$ & Descriptive & $\begin{array}{l}\text { Trainee } \\
\text { psychiatrists } \\
(n=40)\end{array}$ & Questionnaire & $\begin{array}{l}\text { The effectiveness } \\
\text { of an educational } \\
\text { elder abuse } \\
\text { intervention over } \\
\text { three months and } \\
\text { its impact on } \\
\text { professionals' } \\
\text { knowledge and } \\
\text { practice regarding } \\
\text { identification and } \\
\text { management of } \\
\text { potentially abusive } \\
\text { situations }\end{array}$ & $\begin{array}{l}\text { Compared with baseline, participants scored higher and } \\
\text { identified more definitely abusive and possibly abusive } \\
\text { situations immediately post-intervention. At three-month } \\
\text { follow-up, participants reported higher confidence in } \\
\text { managing abuse and considered it more frequently, but did not } \\
\text { ask older people and their carers about abuse more frequently. } \\
\text { Two participants detected abuse in the three months before } \\
\text { the intervention, compared with } 2 \text { in the same period } \\
\text { afterward }\end{array}$ \\
\hline Cooper et al. (2009) & & $\begin{array}{l}\text { Systematic } \\
\text { review }\end{array}$ & & & $\begin{array}{l}\text { Professionals' } \\
\text { knowledge, } \\
\text { detection, } \\
\text { reporting, } \\
\text { and intervention } \\
\text { of elder abuse }\end{array}$ & $\begin{array}{l}\text { Thirty-two articles were reviewed that included } 21 \text { surveys } \\
\text { (of } 5325 \text { professionals), nine analyses of elder abuse reports to } \\
\text { statutory bodies, and two intervention studies. Compatible } \\
\text { results were pooled in a meta-analysis. Professionals } \\
\text { underestimated prevalence of elder abuse and only a quarter } \\
\text { of physicians knew the American Medical Association elder } \\
\text { abuse guidelines. Of health care professionals, } 33.7 \% \text { had } \\
\text { detected a case of elder abuse in the last year, and half of } \\
\text { the detected abuse cases were reported. There was an } \\
\text { association between recalling training in abuse and higher } \\
\text { reporting rates. Face-to-face training was effective in } \\
\text { increasing knowledge, although no intervention studies had } \\
\text { investigated whether detection and reporting of abuse could } \\
\text { also be increased through education. Current evidence would } \\
\text { support the development and testing of interventions to } \\
\text { increase professionals' detection and reporting of abuse }\end{array}$ \\
\hline
\end{tabular}


Table 1

(Continued)

\begin{tabular}{|c|c|c|c|c|c|c|}
\hline $\begin{array}{l}\text { Authors and } \\
\text { publication date }\end{array}$ & Country & Type of study & Sample & $\begin{array}{l}\text { Information } \\
\text { gathering } \\
\text { techniques }\end{array}$ & Analysed variables & Main results \\
\hline $\begin{array}{l}\text { Daly and Coffey } \\
\text { (2010) }\end{array}$ & Ireland & Descriptive & $\begin{array}{l}\text { Nurses and care } \\
\text { assistants working } \\
\text { in long-term care } \\
\text { settings }(n=114)\end{array}$ & Questionnaire & $\begin{array}{l}\text { Perceptions of } \\
\text { elder abuse, level } \\
\text { of education, how } \\
\text { knowledge was } \\
\text { gained on elder } \\
\text { abuse, confidence } \\
\text { about recognising } \\
\text { elder abuse and } \\
\text { desire to obtain } \\
\text { further education } \\
\text { on elder abuse }\end{array}$ & $\begin{array}{l}\text { There was a high level of uncertainty about what constituted } \\
\text { elder abuse }\end{array}$ \\
\hline $\begin{array}{l}\text { Daly and Jogerst } \\
\text { (2005) }\end{array}$ & USA & Descriptive & $\begin{array}{l}\text { Adult protective } \\
\text { service } \\
\text { caseworkers } \\
(n=302)\end{array}$ & Delphi panel & $\begin{array}{l}\text { Types of elder } \\
\text { mistreatment, } \\
\text { indicators of elder } \\
\text { mistreatment per } \\
\text { type, and } \\
\text { demographic } \\
\text { variables }\end{array}$ & $\begin{array}{l}\text { The different types of abuse (emotional abuse, exploitation of } \\
\text { finances and/or property, neglect, physical abuse, and sexual } \\
\text { abuse) had some similar and some extremely different } \\
\text { indicators that singly and together expanded their definition }\end{array}$ \\
\hline Daly et al. (2012) & USA & Descriptive & $\begin{array}{l}\text { Critical care nurses } \\
(n=10)\end{array}$ & Interview & $\begin{array}{l}\text { Types, suspicions, } \\
\text { reporting, barriers } \\
\text { to reporting elder } \\
\text { abuse, legislation, } \\
\text { and improvement } \\
\text { in practice }\end{array}$ & $\begin{array}{l}\text { Nurses reported the kinds of abuse they may encounter as } \\
\text { emotional abuse, financial exploitation, neglect, and physical } \\
\text { abuse. They reported being suspicious of elder abuse if the } \\
\text { patient (1) depicted being malnourished and unkempt; (2) had } \\
\text { bruising or other marks on the body with no reasonable } \\
\text { explanation, (3) had burn marks in places where the patient } \\
\text { could not reach, ( } 4 \text { ) could not provide a clear } \\
\text { explanation/reluctance to answer questions, or (5) if a family } \\
\text { member hovered or appeared uncomfortable with health care } \\
\text { professionals present. In most instances, the nurses reported } \\
\text { suspected abuse to the patient's physician or the unit's social } \\
\text { worker and they did not know what happens after the } \\
\text { allegation was reported. Reasons provided why patients were } \\
\text { reluctant to report included: being scared, feeling they deserve } \\
\text { the abuse, it may get worse when they get home, fear of being } \\
\text { relocated to a nursing home or different institution, fear of } \\
\text { abandonment, they did not want to get their children in } \\
\text { trouble, dependence. Suggestions for improving the practice: } \\
\text { conduct health history in private, ask safety questions on } \\
\text { admission assessment, readdress the issue of elder abuse at } \\
\text { discharge from the unit, establish the reporting of elder abuse } \\
\text { as a priority for the unit, and offer elder abuse education } \\
\text { in addition to that required by law }\end{array}$ \\
\hline
\end{tabular}


Table

(Continued)

\begin{tabular}{|c|c|c|c|c|c|c|}
\hline $\begin{array}{l}\text { Authors and } \\
\text { publication date }\end{array}$ & Country & Type of study & Sample & $\begin{array}{l}\text { Information } \\
\text { gathering } \\
\text { techniques }\end{array}$ & Analysed variables & Main results \\
\hline $\begin{array}{l}\text { Davis and Konishi } \\
\text { (2007) }\end{array}$ & Japan & Descriptive & $\begin{array}{l}\text { Master's students } \\
\text { and clinical } \\
\text { teachers with BSN } \\
\text { degrees at a } \\
\text { nursing college } \\
(n=24)\end{array}$ & Questionnaire & $\begin{array}{l}\text { The meaning } \\
\text { of and the } \\
\text { experiences with } \\
\text { whistleblowing }\end{array}$ & $\begin{array}{l}\text { Fourteen nurses answered the hypothetical question of } \\
\text { whether they would report another colleague saying they } \\
\text { would report a nurse and six said they would not, but } 17 \text { said } \\
\text { they would report a physician and only one said she would not } \\
\text { report. Some nurses had already reported report a nurse or a } \\
\text { physician in their work setting. Many thought that reporting } \\
\text { nurses or physicians would result in someone taking action to } \\
\text { change the situation, and that their nurse colleagues and their } \\
\text { senior nurse would support them. When asked if physicians } \\
\text { would support them if they reported a nurse, } 10 \text { said yes, but } \\
\text { only six said yes if this involved reporting a physician. All the } \\
\text { nurses who responded said they would whistleblow } \\
\text { depending on the situation; this was especially true when } \\
\text { considering reporting a physician. Reasons given for reporting } \\
\text { were: the results of first going directly to the person whom } \\
\text { they thought to be the wrongdoer; concerns about the effects } \\
\text { of wrongdoing on the patient; and the belief that the head } \\
\text { nurse should receive such information because she has overall } \\
\text { responsibility for the hospital unit }\end{array}$ \\
\hline Dow et al. (2013) & Australia & Descriptive & $\begin{array}{l}\text { Health } \\
\text { professionals from } \\
\text { metropolitan } \\
\text { health services and } \\
\text { university health } \\
\text { care students } \\
(n=247)\end{array}$ & Questionnaire & $\begin{array}{l}\text { Identification } \\
\text { of elder abuse, } \\
\text { demographic } \\
\text { variables, been } \\
\text { taught about } \\
\text { identifying elder } \\
\text { abuse or what to do } \\
\text { in case of suspected } \\
\text { elder abuse }\end{array}$ & $\begin{array}{l}\text { Significantly more students than health professionals } \\
\text { identified locking someone in the house alone all day and } \\
\text { restraining someone in a chair as abusive. Tests found no } \\
\text { statistically significant associations between demographic } \\
\text { variables and identifying strategies categorised as abusive. }\end{array}$ \\
\hline Dyer et al. (2005) & USA & Descriptive & $\begin{array}{l}\text { Adult protective } \\
\text { service workers } \\
(n=24)\end{array}$ & Interview & $\begin{array}{l}\text { Indicators, } \\
\text { definitions and } \\
\text { criteria of caregiver } \\
\text { neglect and } \\
\text { self-neglect, and } \\
\text { demographic } \\
\text { variables }\end{array}$ & $\begin{array}{l}\text { The participants cited environmental filth, poor personal } \\
\text { hygiene and health related factors as the three most common } \\
\text { indicators. The definition of self-neglect was best generalised } \\
\text { as an inability or unwillingness to provide for care for oneself. } \\
\text { Neglect was defined as the failure of a caregiver to provide } \\
\text { necessary goods and services to a client. When asked to } \\
\text { distinguish between self-neglect and caregiver neglect, } 44 \% \\
\text { of the respondents noted that the presence of a caregiver } \\
\text { indicated caregiver neglect. Participants were generally } \\
\text { comfortable validating self-neglect, but were concerned about } \\
\text { falsely identifying a caregiver as neglectful }\end{array}$ \\
\hline Ellis et al. (2014) & & $\begin{array}{l}\text { Theoretical } \\
\text { essay }\end{array}$ & & & & \\
\hline $\begin{array}{l}\text { Erlingsson et al. } \\
\text { (2012) }\end{array}$ & $\begin{array}{l}\text { Sweden } \\
\text { and Japan }\end{array}$ & Descriptive & $\begin{array}{l}\text { Community-based } \\
\text { nurses and public } \\
\text { health nurses } \\
(n=205)\end{array}$ & Questionnaire & $\begin{array}{l}\text { Nurses' response } \\
\text { patterns }\end{array}$ & $\begin{array}{l}\text { Nurses' response patterns in the aggregated data were similar } \\
\text { across all three hypothetical cases. However, there were also } \\
\text { differences between Swedish and Japanese responses. Swedish } \\
\text { responses were generally practical, action oriented } \\
\text { and involved increased levels of suspicion and personal } \\
\text { intervention to achieve increased control. Japanese responses } \\
\text { concerned better understanding that involved the family } \\
\text { members and their situation, focusing on interventions } \\
\text { grounded in collaboration }\end{array}$ \\
\hline
\end{tabular}


Table

(Continued)

\begin{tabular}{|c|c|c|c|c|c|c|}
\hline $\begin{array}{l}\text { Authors and } \\
\text { publication date }\end{array}$ & Country & Type of study & Sample & $\begin{array}{l}\text { Information } \\
\text { gathering } \\
\text { techniques }\end{array}$ & Analysed variables & Main results \\
\hline $\begin{array}{l}\text { Gironda et al. } \\
\text { (2010) }\end{array}$ & & $\begin{array}{l}\text { Theoretical } \\
\text { essay }\end{array}$ & & & & \\
\hline Granville (2001) & USA & Descriptive & $\begin{array}{l}\text { Registered nurses } \\
(n=372)\end{array}$ & Questionnaire & $\begin{array}{l}\text { The likelihood } \\
\text { of reporting an } \\
\text { intentional versus } \\
\text { an unintentional } \\
\text { wrongdoing }\end{array}$ & $\begin{array}{l}\text { Perceived intentionality was related to questionable } \\
\text { behaviour. The severity of the wrongdoing performed a } \\
\text { significant role in determining whether or not an incident } \\
\text { should be reported. Nurses indicated they would confront the } \\
\text { wrongdoer about the unintentional incidents instead } \\
\text { of reporting it to an immediate supervisor }\end{array}$ \\
\hline $\begin{array}{l}\text { Halphen et al. } \\
\text { (2009) }\end{array}$ & & $\begin{array}{l}\text { Theoretical } \\
\text { essay }\end{array}$ & & & & \\
\hline $\begin{array}{l}\text { Hempton et al. } \\
\text { (2010) }\end{array}$ & Australia & Descriptive & $\begin{array}{l}\text { Health } \\
\text { professionals from } \\
\text { metropolitan } \\
\text { hospitals, older } \\
\text { volunteers and } \\
\text { carers of older } \\
\text { people with } \\
\text { dementia }(n=570)\end{array}$ & Questionnaire & $\begin{array}{l}\text { Perceptions } \\
\text { of elder abuse }\end{array}$ & $\begin{array}{l}\text { Significantly more health professionals than older people } \\
\text { identified locking someone in the house alone all day, } \\
\text { restraining someone in a chair and hiding medication in food } \\
\text { as abusive. There were no significant differences between } \\
\text { older volunteers and carers in their perceptions of elder abuse. } \\
\text { A significant minority ( } 40.8 \% \text { ) of health professionals and over } \\
50 \% \text { of carers did not identify locking the care recipient alone } \\
\text { in the house all day as abusive }\end{array}$ \\
\hline Hirst (2002) & Canada & Descriptive & $\begin{array}{l}\text { Registered nurses } \\
\text { working in urban } \\
\text { long-term care } \\
\text { institutions }(n=10)\end{array}$ & $\begin{array}{l}\text { Interview and } \\
\text { focus groups }\end{array}$ & $\begin{array}{l}\text { Perceptions of } \\
\text { resident abuse }\end{array}$ & $\begin{array}{l}\text { Five categories of resident abuse characteristics emerged: } \\
\text { perception of hurt felt by older residents, acts of omission } \\
\text { or commission, context of care, intentional or unintentional, } \\
\text { and behavioural clusters }\end{array}$ \\
\hline $\begin{array}{l}\text { Joubert and } \\
\text { Posenelli (2009) }\end{array}$ & Australia & Descriptive & $\begin{array}{l}\text { Hospital staff } \\
(n \text { phase } 1=166) \\
(n \text { phase } 2=11) \\
(n \text { phase } 3=11)\end{array}$ & $\begin{array}{l}\text { Questionnaire, } \\
\text { interview and } \\
\text { focus group }\end{array}$ & $\begin{array}{l}\text { Hospital staff's } \\
\text { response to aged } \\
\text { abuse }\end{array}$ & $\begin{array}{l}\text { Seventy-three per cent of participants were familiar with the } \\
\text { concept of aged abuse; } 14 \% \text { had received any education or } \\
\text { training on how to detect or manage this group of patients; } \\
32 \% \text { indicated that they had a good understanding while } 54 \% \\
\text { said that they had a fair to poor understanding of aged abused; } \\
47 \% \text { had never suspected abuse in any of their elderly patients } \\
\text { within the previous twelve months. Staff suspicion was } \\
\text { aroused during their observation of the patient and their } \\
\text { family or carer ( } 22 \% \text { ), during routine assessment ( } 46 \% \text { ) or } \\
\text { when the elderly person was referred to them by another } \\
\text { member of the staff ( } 32 \% \text { ). The highest frequency of abuse } \\
\text { suspected was ascribed to an adult child ( } 39 \% \text { ) with the same } \\
\text { frequencies reported for the spouse, carer, and residential care } \\
\text { facility ( } 10 \% \text { ). Information from interviews focused on three } \\
\text { topics: staff perception of satisfaction with the care offered; } \\
\text { ethical dilemmas faced by interviewees, and staff attitudes } \\
\text { towards mandatory reporting. Four main themes emerged } \\
\text { from the focus group: issues around the patient, issues around } \\
\text { the carer, issues around the patient, issues around health care } \\
\text { professionals and service provision, and issues around types } \\
\text { of abuse }\end{array}$ \\
\hline Kennedy (2005) & USA & Descriptive & $\begin{array}{l}\text { Family physicians } \\
\text { and general } \\
\text { internists }(n=392)\end{array}$ & Questionnaire & $\begin{array}{l}\text { Experience, } \\
\text { knowledge and } \\
\text { attitudes towards } \\
\text { elder mistreatment }\end{array}$ & $\begin{array}{l}\text { Nearly } 72 \% \text { reported no exposure or only minimal exposure } \\
\text { to elder mistreatment. More than half of the participants } \\
\text { reported that they had never identified a case of elder } \\
\text { mistreatment. Participants estimated its prevalence as roughly } \\
\text { less than } 25 \% \text { of the prevalence documented in the medical } \\
\text { literature, and they were reluctant to accept the problem as } \\
\text { universal. More than } 60 \% \text { reported that they had never asked } \\
\text { their elderly patients about abuse. Family physicians tended to } \\
\text { have a better knowledge of elder mistreatment and were more } \\
\text { aware of management options }\end{array}$ \\
\hline
\end{tabular}


Table 1

\begin{tabular}{|c|c|c|c|c|c|c|}
\hline $\begin{array}{l}\text { Authors and } \\
\text { publication date }\end{array}$ & Country & Type of study & Sample & $\begin{array}{l}\text { Information } \\
\text { gathering } \\
\text { techniques }\end{array}$ & Analysed variables & Main results \\
\hline $\begin{array}{l}\text { Kennelly et al. } \\
\text { (2007) }\end{array}$ & Ireland & Descriptive & $\begin{array}{l}\text { Non-consultant } \\
\text { hospital doctors } \\
\text { working in internal } \\
\text { medicine and } \\
\text { medical social } \\
\text { workers }(n=39)\end{array}$ & Questionnaire & $\begin{array}{l}\text { Understanding of } \\
\text { the term elder } \\
\text { abuse, its perceived } \\
\text { prevalence, } \\
\text { attitudes, } \\
\text { identification of } \\
\text { potential risk } \\
\text { factors, training } \\
\text { received, } \\
\text { awareness of the } \\
\text { existing } \\
\text { government policy, } \\
\text { the frequency of } \\
\text { exposure to cases } \\
\text { and their } \\
\text { management }\end{array}$ & $\begin{array}{l}\text { Forty-five per cent had never heard the term "elder abuse", } \\
\text { and } 30 \% \text { had read any literature at any stage on the topic. No } \\
\text { doctors had ever received any formal training, and only one } \\
\text { doctor had heard of guidelines for its management. Eighty-five } \\
\text { per cent felt elder abuse was common, and all felt it was } \\
\text { under-reported. Eighty-five per cent of doctors had treated at } \\
\text { least one suspected case of elder abuse in the last year. All } \\
\text { MSWs had read literature or had received formal training on } \\
\text { the topic, } 58 \% \text { were aware of management guidelines, however } \\
\text { only } 10 \% \text { were able to name them. Both groups said they } \\
\text { sought the advice of senior colleagues when managing } \\
\text { suspected cases of abuse and } 46 \% \text { of the participants would } \\
\text { feel uncomfortable using the label of "elder abuse" }\end{array}$ \\
\hline $\begin{array}{l}\text { Killick and Taylor } \\
\text { (2009) }\end{array}$ & & $\begin{array}{l}\text { Systematic } \\
\text { review }\end{array}$ & & & $\begin{array}{l}\text { Factors influencing } \\
\text { professional } \\
\text { decision making at } \\
\text { the point of first } \\
\text { referral }\end{array}$ & $\begin{array}{l}\text { Nineteen articles were reviewed. The factors identified by the } \\
\text { research were classified into three categories: case factors, } \\
\text { professional factors and agency factors. The studies identified } \\
\text { case factors relating to the victim, the caregiver, and the wider } \\
\text { social and economic situation. The frequency and severity of } \\
\text { abuse received little attention. The majority of included } \\
\text { studies focused primarily on practitioner factors. The influence } \\
\text { of agency factors was addressed by only two of the included } \\
\text { studies }\end{array}$ \\
\hline Ko and Koh (2012) & South Korea & Descriptive & $\begin{array}{l}\text { Hospital nurses } \\
(n=365)\end{array}$ & Questionnaire & $\begin{array}{l}\text { Willingness to } \\
\text { report suspected } \\
\text { elder abuse and its } \\
\text { related factors }\end{array}$ & $\begin{array}{l}\text { Of the participants, } 18.6 \% \text { were not willing to report suspected } \\
\text { elder abuse. Fewer years in clinical work, a higher level of } \\
\text { knowledge on elder abuse law, and the perception of more } \\
\text { severe abuse were found to be significant predictors of } \\
\text { willingness to report elder abuse }\end{array}$ \\
\hline Leddy et al. (2014) & USA & Descriptive & $\begin{array}{l}\text { Obstetricians and } \\
\text { gynaecologists } \\
(n=122)\end{array}$ & Questionnaire & $\begin{array}{l}\text { Knowledge, } \\
\text { attitudes, and } \\
\text { practice regarding } \\
\text { elder abuse }\end{array}$ & $\begin{array}{l}\text { Eighty-one per cent had never reported a case of abuse. } \\
\text { Younger males reported different clinical practice patterns } \\
\text { than other groups. Generally, participants were } \\
\text { knowledgeable about risk factors and issues about elder abuse, } \\
\text { but several knowledge gaps were identified. Most considered } \\
\text { that elder abuse screening was within their professional } \\
\text { purview. Half of the respondents cited time constraints as a } \\
\text { barrier to screening }\end{array}$ \\
\hline
\end{tabular}


Table

\begin{tabular}{|c|c|c|c|c|c|c|}
\hline $\begin{array}{l}\text { Authors and } \\
\text { publication date }\end{array}$ & Country & Type of study & Sample & $\begin{array}{l}\text { Information } \\
\text { gathering } \\
\text { techniques }\end{array}$ & Analysed variables & Main results \\
\hline Liao et al. (2009) & USA & Descriptive & $\begin{array}{l}\text { Hospice and } \\
\text { palliative care } \\
\text { professionals and } \\
\text { adult protective } \\
\text { service workers } \\
(n=96)\end{array}$ & Questionnaire & $\begin{array}{l}\text { Differences in elder } \\
\text { mistreatment } \\
\text { reporting } \\
\text { threshold, and } \\
\text { factors for not } \\
\text { reporting elder } \\
\text { mistreatment }\end{array}$ & $\begin{array}{l}\text { Significant differences were found in the threshold of } \\
\text { reporting between APS and HPC professionals in all the } \\
\text { mistreatment cases but the most severe. APS was more likely } \\
\text { to accept reports of elder mistreatment. HPC professionals had } \\
\text { reported a mean of } 2.52( \pm 2.79, S D) \text { cases in the last } 5 \text { years, } \\
33.3 \% \text { had not reported a single case in the last } 5 \text { years, } 24.1 \% \\
\text { had not suspected any cases of mistreatment in the last } 5 \\
\text { years, and } 29.6 \% \text { had suspected cases that they did not report. } \\
\text { The median difference between the total number of suspected } \\
\text { and reported cases was } 2( \pm 4.6, S D) \text {. Eleven per cent had } \\
\text { ethical concerns about reporting and } 63 \% \text { were concerned } \\
\text { about practical consequences of reporting. Thirty-seven per } \\
\text { cent correctly identified the reporting agencies that have } \\
\text { jurisdiction over abuse that occurs in long-term care. Correct } \\
\text { identification of long-term care reporting agencies correlated } \\
\text { with whether the HPC professional had training in elder } \\
\text { mistreatment }(r=0.35, p=0.009) \text {. Ninety-six per cent would } \\
\text { report physical abuse that they witnessed, and sixty-three } \\
\text { would report abuse verbalised by the patient }\end{array}$ \\
\hline $\begin{array}{l}\text { Malmedal et al. } \\
\text { (2009) }\end{array}$ & Norway & Descriptive & $\begin{array}{l}\text { Nursing staff in } \\
\text { nursing homes } \\
(n=616)\end{array}$ & Questionnaire & $\begin{array}{l}\text { Attitudes on } \\
\text { reporting acts of } \\
\text { inadequate care, } \\
\text { age, education, } \\
\text { and length of } \\
\text { experience of } \\
\text { working in the } \\
\text { healthcare services }\end{array}$ & $\begin{array}{l}\text { Participants held a positive attitude towards reporting acts of } \\
\text { inadequate care committed by their colleagues. There were } \\
\text { significant differences between the age groups and between } \\
\text { educational levels regarding the attitudes of staff towards } \\
\text { reporting. Compared with younger staff, the older staff seemed } \\
\text { to be more reluctant to report colleagues, to feel less brave, to } \\
\text { be more afraid of what would happen to them if they reported, } \\
\text { and to agree that it is best to deal with such matters internally. } \\
\text { Regarding education, it seemed that a higher educational level } \\
\text { was related with a more positive attitude towards a } \\
\text { willingness to report and less fear of negative sanctions. There } \\
\text { were significant differences between groups with varying } \\
\text { lengths of experience in respect of two statements: "It is no use } \\
\text { reporting anything; nothing will happen anyway" ( } p=0.009) \\
\text { and "It is best to deal with such matters internally" ( } p=0.003)\end{array}$ \\
\hline $\begin{array}{l}\text { Mandiracioglu } \\
\text { et al. (2006) }\end{array}$ & Turkey & Descriptive & $\begin{array}{l}\text { Emergency health } \\
\text { care providers } \\
\text { teams }(n=125)\end{array}$ & Questionnaire & $\begin{array}{l}\text { Knowledge, } \\
\text { attitudes, and } \\
\text { beliefs towards the } \\
\text { identification } \\
\text { and management } \\
\text { of abused older } \\
\text { people }\end{array}$ & $\begin{array}{l}\text { Of the respondents, } 13.6 \% \text { had never identified an abused older } \\
\text { person. The health care personnel working at university } \\
\text { emergency department had a better knowledge than state } \\
\text { hospital personnel about elder abuse. There was a significant } \\
\text { difference on the "willingness to report abuse" scores between } \\
\text { physicians and nurses. Most of the participants felt } \\
\text { uncomfortable in asking questions about older people abuse. } \\
\text { A majority of them believed that it is the older person's } \\
\text { responsibility to report their symptoms related abuse. Most } \\
\text { of the participants perceived elder abuse to be uncommon in } \\
\text { Turkey and } 24 \% \text { reported they had not received formal training } \\
\text { on older people abuse }\end{array}$ \\
\hline
\end{tabular}


Table

\begin{tabular}{|c|c|c|c|c|c|c|}
\hline $\begin{array}{l}\text { Authors and } \\
\text { publication date }\end{array}$ & Country & Type of study & Sample & $\begin{array}{l}\text { Information } \\
\text { gathering } \\
\text { techniques }\end{array}$ & Analysed variables & Main results \\
\hline $\begin{array}{l}\text { McCool et al. } \\
\text { (2009) }\end{array}$ & USA & Descriptive & $\begin{array}{l}\text { Employees of nursing } \\
\text { facilities } \\
(n \text { questionnaire }=49) \\
(n \text { interview }=22)\end{array}$ & $\begin{array}{l}\text { Questionnaire } \\
\text { and interview }\end{array}$ & $\begin{array}{l}\text { Demographic data, } \\
\text { personal } \\
\text { experiences with } \\
\text { suspected elder } \\
\text { abuse and } \\
\text { reporting, } \\
\text { legislation, facility } \\
\text { protocols, and } \\
\text { opinions on } \\
\text { mandatory } \\
\text { reporting }\end{array}$ & $\begin{array}{l}\text { Fifty-three per cent of the respondents reported that they have } \\
\text { suspected a case of elder abuse; } 35 \% \text { of those respondents } \\
\text { indicated that they did not report all the cases of abuse they } \\
\text { have suspected. Most of the respondents answered correctly } \\
\text { the questions about reporting abuse and consent. Four themes } \\
\text { emerged from the interviews: the need for more staff } \\
\text { education/training; difficulty in making judgments about } \\
\text { whether the situation needs to be reported; barriers to } \\
\text { reporting, and a sense that some abuse situations may occur } \\
\text { because the staff is overworked, inexperienced, and/or } \\
\text { frustrated from dealing with difficult residents }\end{array}$ \\
\hline $\begin{array}{l}\text { McCreadie et al. } \\
(2000)\end{array}$ & $\begin{array}{l}\text { United } \\
\text { Kingdom }\end{array}$ & Descriptive & $\begin{array}{l}\text { General practitioners } \\
(n=291)\end{array}$ & Questionnaire & $\begin{array}{l}\text { Demographic } \\
\text { characteristics, } \\
\text { practice } \\
\text { characteristics, } \\
\text { home visiting, } \\
\text { education, training, } \\
\text { and diagnosis } \\
\text { of abuse }\end{array}$ & $\begin{array}{l}\text { Forty-five per cent had diagnosed elder abuse in the previous } \\
\text { year. The strongest factor predicting diagnosis of abuse was } \\
\text { knowledge of five or more risk situations }\end{array}$ \\
\hline $\begin{array}{l}\text { Meeks-Sjostrom } \\
\text { (2013) }\end{array}$ & USA & Descriptive & $\begin{array}{l}\text { Registered nurses } \\
(n=84)\end{array}$ & Questionnaire & $\begin{array}{l}\text { Applied knowledge } \\
\text { (assessment cues) } \\
\text { of elder abuse, use } \\
\text { of intuition in } \\
\text { nursing, years of } \\
\text { experience as a RN, } \\
\text { clinical level of } \\
\text { practice status, and } \\
\text { the clinical } \\
\text { decision outcomes } \\
\text { (interventions) }\end{array}$ & $\begin{array}{l}\text { RNs applied knowledge (assessment cues) and years worked } \\
\text { as a RN significantly predicted clinical decision outcomes } \\
\text { (interventions), There were no differences in applied } \\
\text { knowledge (assessment cues) of elder abuse, intuition use in } \\
\text { nursing, years working as a RN, clinical level of practice status, } \\
\text { and clinical decision outcomes (interventions) between RNs } \\
\text { who received elder abuse education at orientation and those } \\
\text { who did not receive the education }\end{array}$ \\
\hline $\begin{array}{l}\text { Pillemer et al. } \\
\text { (2011) }\end{array}$ & USA & Descriptive & $\begin{array}{l}\text { Academic research } \\
\text { experts and } \\
\text { practitioner experts }\end{array}$ & $\begin{array}{l}\text { Research-to- } \\
\text { practice } \\
\text { consensus } \\
\text { workshops }\end{array}$ & $\begin{array}{l}\text { Recommendations } \\
\text { from expert } \\
\text { practitioners and } \\
\text { researchers } \\
\text { regarding future } \\
\text { directions for } \\
\text { research on elder } \\
\text { abuse prevention }\end{array}$ & $\begin{array}{l}\text { Ten key recommendations for future research were proposed. } \\
\text { The recommendations included the following priority areas: } \\
\text { defining elder abuse, providing researchers with access to } \\
\text { victims and abusers, determining the best approaches in } \\
\text { treating abusers, exploiting existing data sets, identifying risk } \\
\text { factors, understanding the impact of cultural factors, } \\
\text { improving programme evaluation, establishing how cognitive } \\
\text { impairment affects legal investigations, promoting studies of } \\
\text { financial and medical forensics, and improving professional } \\
\text { reporting and training }\end{array}$ \\
\hline $\begin{array}{l}\text { Richardson et al. } \\
(2002)\end{array}$ & $\begin{array}{l}\text { United } \\
\text { Kingdom }\end{array}$ & $\begin{array}{l}\text { Randomised } \\
\text { controlled trial }\end{array}$ & $\begin{array}{l}\text { Nurses, care assistants } \\
\text { and social workers } \\
(n=64)\end{array}$ & Questionnaire & $\begin{array}{l}\text { Type of training } \\
\text { (attending an } \\
\text { educational course } \\
\text { vs. printed } \\
\text { educational } \\
\text { material) } \\
\text { knowledge and } \\
\text { management of } \\
\text { abuse, attitude } \\
\text { towards people } \\
\text { with dementia, } \\
\text { and burnout }\end{array}$ & $\begin{array}{l}\text { There was a lack of knowledge of good management in dealing } \\
\text { with elder abuse. Those who attended an educational course } \\
\text { improved their knowledge after the intervention. There was a } \\
\text { ceiling effect with those who knew more learning less. } \\
\text { Attending and educational course and low baseline knowledge } \\
\text { predicted learning. Positive attitude towards people with } \\
\text { dementia correlated with baseline knowledge, but did not } \\
\text { predict knowledge }\end{array}$ \\
\hline
\end{tabular}


Table 1

(Continued)

\begin{tabular}{|c|c|c|c|c|c|c|}
\hline $\begin{array}{l}\text { Authors and } \\
\text { publication date }\end{array}$ & Country & Type of study & Sample & $\begin{array}{l}\text { Information } \\
\text { gathering } \\
\text { techniques }\end{array}$ & Analysed variables & Main results \\
\hline Rinker (2009) & USA & Descriptive & $\begin{array}{l}\text { Emergency medical } \\
\text { services and } \\
\text { hospital care } \\
\text { providers }(n=400)\end{array}$ & Questionnaire & $\begin{array}{l}\text { Perception, } \\
\text { knowledge and } \\
\text { ability to identify } \\
\text { patients that were } \\
\text { potential victims } \\
\text { of elder abuse } \\
\text { and/or neglect }\end{array}$ & $\begin{array}{l}\text { During the past } 12 \text { months, } 51.3 \% \text { of those surveyed did not } \\
\text { have reason to suspect abuse or neglect, participants ( } 83.5 \% \text { ) } \\
\text { believed a decubital ulcer was a positive indicator of } \\
\text { abuse/neglect and } 92.8 \% \text { indicated that the elderly could suffer } \\
\text { from injuries similar to "shaken-baby syndrome". Sixty-nine } \\
\text { per cent identified skin bruises as a possible indicator of abuse, } \\
\text { and } 71 \% \text { indicated that burns are not common in the elderly } \\
\text { and could be another sign of elder abuse. One-in-three } \\
\text { providers indicated they would suspect other reasons } \\
\text { (dementia, depression, etc.) for the report of a sexual assault in } \\
\text { an elderly patient. The majority ( } 89.0 \% \text { ) of respondents knew } \\
\text { that they were obligated to report cases of (suspected) elder } \\
\text { abuse or neglect to law enforcement or social services } \\
\text { personnel. Sixty-six per cent of the respondents felt that elder } \\
\text { abuse was a medical problem, whereas } 20.3 \% \text { felt it was a } \\
\text { social problem. Over } 95 \% \text { of the participants suspected the } \\
\text { existence of abuse, neglect and domestic violence among the } \\
\text { elderly were not rare events }\end{array}$ \\
\hline $\begin{array}{l}\text { Rodriguez et al. } \\
\text { (2006) }\end{array}$ & USA & Descriptive & $\begin{array}{l}\text { Primary care } \\
\text { physicians }(n=20)\end{array}$ & Interview & $\begin{array}{l}\text { Physician's } \\
\text { perspectives on } \\
\text { mandated } \\
\text { reporting of elder } \\
\text { abuse }\end{array}$ & $\begin{array}{l}\text { Paradoxes emerged from analyses of interview transcripts } \\
\text { related to } 3 \text { topical areas: physician-patient relationship; } \\
\text { increase and decrease in patient quality of life; and presence } \\
\text { and loss of physician control. All } 20 \text { physicians referred to } \\
\text { these paradoxes. These paradoxes appeared to be primarily } \\
\text { hidden or unconscious, yet they influenced the conscious } \\
\text { decision process of whether to report }\end{array}$ \\
\hline $\begin{array}{l}\text { Sandmoe and } \\
\text { Kirkevold (2013) }\end{array}$ & Norway & Descriptive & $\begin{array}{l}\text { Nurse managers } \\
\text { and department } \\
\text { managers }(n=52)\end{array}$ & Interview & $\begin{array}{l}\text { Identification and } \\
\text { handling of abused } \\
\text { older clients }\end{array}$ & $\begin{array}{l}\text { Half of the participants had identified cases during the } \\
\text { previous year, but the interviews indicated that abuse was } \\
\text { discovered more often than the participants stated. The role } \\
\text { of the participants in identifying abuse cases was not clear. } \\
\text { Identification and handling of abused older clients was based } \\
\text { on clinical experience and less on knowledge through } \\
\text { professional training and education. The participants } \\
\text { emphasised the importance of individualising interventions, } \\
\text { taking appropriate action depending on the severity of a } \\
\text { situation and finding a solution that was satisfactory to both } \\
\text { the victim and abuser. All participants stated that } \\
\text { interdisciplinary collaboration was primarily limited to } \\
\text { discussion and counselling. Several participants found that few } \\
\text { people were willing to play an active role in case management. } \\
\text { In general, the participants believed that handling neglect } \\
\text { cases was appropriate, whereas strategies for handling } \\
\text { financial abuse were described as insufficient and very difficult }\end{array}$ \\
\hline
\end{tabular}


Table

\begin{tabular}{|c|c|c|c|c|c|c|}
\hline $\begin{array}{l}\text { Authors and } \\
\text { publication date }\end{array}$ & Country & Type of study & Sample & $\begin{array}{l}\text { Information } \\
\text { gathering } \\
\text { techniques }\end{array}$ & Analysed variables & Main results \\
\hline $\begin{array}{l}\text { Sandmoe et al. } \\
\text { (2011) }\end{array}$ & $\begin{array}{l}\text { Norway and } \\
\text { Australia }\end{array}$ & Descriptive & $\begin{array}{l}\text { Nurses, auxiliary } \\
\text { nurses and care } \\
\text { workers }(n=20)\end{array}$ & Interview & $\begin{array}{l}\text { Handling of abused } \\
\text { older clients }\end{array}$ & $\begin{array}{l}\text { The similarity of the information obtained in the two countries } \\
\text { was very high. The nature of the interventions differed based } \\
\text { on the type and seriousness of the abuse and the participants' } \\
\text { considerations of the client's cognitive capacity. The } \\
\text { participants experienced the intervention as a long-lasting } \\
\text { process with changing goals and problem-solving activities } \\
\text { that displayed phases of improvement and aggravation; } \\
\text { however, some cases also called for immediate action. The } \\
\text { clients' and caregivers' attributes, relationships and life } \\
\text { contexts were important factors and constituted the premises } \\
\text { for the participants' intervention. Financial abuse was a more } \\
\text { prominent issue in Australia than in Norway. The managers' } \\
\text { support and the elder protective services were of great } \\
\text { importance to the nurses }\end{array}$ \\
\hline $\begin{array}{l}\text { Schmeidel et al. } \\
\text { (2012) }\end{array}$ & USA & Descriptive & $\begin{array}{l}\text { Nurses, physicians, } \\
\text { and social workers } \\
(n=23)\end{array}$ & Interview & $\begin{array}{l}\text { Professionals' } \\
\text { perspectives } \\
\text { on elder abuse }\end{array}$ & $\begin{array}{l}\text { All professions reported emotional, financial, mental, neglect, } \\
\text { physical, psychological, spousal, and verbal abuse as the kinds } \\
\text { of abuse they may encounter. In addition, physicians reported } \\
\text { isolation and sexual abuse. Social workers also mentioned } \\
\text { self-neglect. Analysis of participants' statements about barriers } \\
\text { to detecting and reporting revealed five major categories: } \\
\text { professional orientation, assessment, interpretation, systems, } \\
\text { and knowledge and education }\end{array}$ \\
\hline Shefet et al. (2007) & Israel & Descriptive & $\begin{array}{l}\text { Physicians, } \\
\text { residents and } \\
\text { specialists in } \\
\text { relevant primary } \\
\text { care fields, from } \\
\text { both outpatient } \\
\text { and inpatient } \\
\text { settings }(n=150)\end{array}$ & Questionnaire & $\begin{array}{l}\text { Self-perception of } \\
\text { knowledge and } \\
\text { skills, reported } \\
\text { case management, } \\
\text { and perceived } \\
\text { intervention } \\
\text { barriers }\end{array}$ & $\begin{array}{l}\text { Perception of knowledge and skills, routine screening } \\
\text { frequency and reported case management all demonstrated } \\
\text { significant improvement between baseline and follow-up. } \\
\text { A clear trend to elevation in detection, evaluation and referral } \\
\text { rates was found. Ranking of intervention barriers was } \\
\text { compared with baseline values and lack of knowledge, lack of } \\
\text { skills and psychological difficulties diminished significantly, } \\
\text { which indicated an improvement in the physicians' attitudes } \\
\text { regarding these barriers }\end{array}$ \\
\hline $\begin{array}{l}\text { Shinan-Altman and } \\
\text { Cohen (2009) }\end{array}$ & Israel & Descriptive & $\begin{array}{l}\text { Nursing aides from } \\
\text { nursing home } \\
(n=208)\end{array}$ & Questionnaire & $\begin{array}{l}\text { Demographic } \\
\text { variables, work } \\
\text { stressors, burnout, } \\
\text { perceived control, } \\
\text { and attitudes } \\
\text { condoning elder } \\
\text { abuse }\end{array}$ & $\begin{array}{l}\text { The mean score of attitudes condoning elder abuse of } 3.24 \\
\text { ( } S D=0.59 \text { ) on a } 1-4 \text { scale indicated a relatively high tendency } \\
\text { to condone abusive behaviours. Condoning abusive behaviours } \\
\text { were closely associated with higher levels of work stressors, } \\
\text { burnout, and low income. Multiple regression analyses } \\
\text { showed that demographic variables, work stressors, burnout, } \\
\text { and perceived control explained } 16 \% \text { of the variance of } \\
\text { attitudes condoning elder abuse. Burnout was a partial } \\
\text { mediator in the relationship between the work stressors } \\
\text { variable and the attitudes condoning elder abuse }\end{array}$ \\
\hline $\begin{array}{l}\text { Sociedad Española } \\
\text { de Geriatría y } \\
\text { Gerontología } \\
(2004)\end{array}$ & Spain & Descriptive & $\begin{array}{l}\text { Health and social } \\
\text { professionals ( } n=7 \\
\text { groups) }\end{array}$ & Focus groups & $\begin{array}{l}\text { Professionals' } \\
\text { perspectives } \\
\text { on elder abuse }\end{array}$ & $\begin{array}{l}\text { Three concepts emerged from the group discussion: neglect, } \\
\text { abuse and maltreatment. Participants indicated the factors } \\
\text { influencing the occurrence of negligence (socioeconomic } \\
\text { context characteristics, the older person's social and personal } \\
\text { characteristics, type of care, and the geographical context) and } \\
\text { the causes of neglect, abuse and mistreatment (factors related } \\
\text { to the professionals, the profession, and institutional factors). } \\
\text { The groups analysed the relationship between risk group, } \\
\text { profession and undesirable behaviour. The proposed solutions } \\
\text { to prevent neglect and abuse were professionals' solutions, } \\
\text { solutions from the professions, and institutional solutions }\end{array}$ \\
\hline
\end{tabular}


Table

(Continued)

\begin{tabular}{|c|c|c|c|c|c|c|}
\hline $\begin{array}{l}\text { Authors and } \\
\text { publication date }\end{array}$ & Country & Type of study & Sample & $\begin{array}{l}\text { Information } \\
\text { gathering } \\
\text { techniques }\end{array}$ & Analysed variables & Main results \\
\hline Starr (2010) & & $\begin{array}{l}\text { Theoretical } \\
\text { essay }\end{array}$ & & & & \\
\hline $\begin{array}{l}\text { Strümpel and } \\
\text { Hackl (2011) }\end{array}$ & $\begin{array}{l}\text { Austria, } \\
\text { Belgium, } \\
\text { Bulgaria, } \\
\text { Germany, } \\
\text { Portugal and } \\
\text { Slovenia }\end{array}$ & Descriptive & $\begin{array}{l}\text { Professionals who } \\
\text { working in } \\
\text { community health } \\
\text { and social services } \\
(n \text { interviews }=59) \\
\text { ( } n \text { question- } \\
\text { naires }=141)\end{array}$ & $\begin{array}{l}\text { Questionnaire } \\
\text { and interview }\end{array}$ & $\begin{array}{l}\text { Professionals' } \\
\text { perspectives on } \\
\text { violence against } \\
\text { older women }\end{array}$ & $\begin{array}{l}\text { In all countries, staff of community health and care services } \\
\text { reported that they had experienced different types of abuse } \\
\text { against older women. Very little attention was paid to specific } \\
\text { gender related issues. Barriers to detecting and reporting } \\
\text { violence against older women were analysed. In the majority } \\
\text { of countries, most organisations considered they were } \\
\text { prepared to deal with abuse against older people and } \\
\text { specifically older women to an average extent. It became } \\
\text { evident through the "Breaking the Taboo 1" project that further } \\
\text { awareness raising as well as longer training courses for staff } \\
\text { members in health and care services for older people at home } \\
\text { were necessary. A total of } 14 \text { trial workshops were carried out. } \\
\text { Preliminary results of the trial workshops were: } 1 \text {. Workshop } \\
\text { participants perceived the topic as very relevant to their work, } \\
\text { but it raised anxiety among some workshop members; } 2 \text {. The } \\
\text { most worthwhile learning experiences could be found through } \\
\text { participants sharing their own experiences and "practical" case } \\
\text { studies; } 3 \text {. Organisational procedures dealing with abuse of } \\
\text { older women had to be clarified before running the workshop; } \\
4 \text {. To be able to plan the training course flexibly according to } \\
\text { the target group and their roles, the time available and the size } \\
\text { of the group attending the workshop; } 5 \text {. The combination two } \\
\text { areas of expertise (social services and violence against women) } \\
\text { proved to be a very important factor in the success of the } \\
\text { workshops; } 6 \text {. Training volunteers as well as staff members; } \\
\text { 7. Workshops with participants from different professional } \\
\text { groups were seen as being very valuable and also rewarding }\end{array}$ \\
\hline $\begin{array}{l}\text { Sugita and Garrett } \\
\text { (2012) }\end{array}$ & USA & Descriptive & $\begin{array}{l}\text { Oral health care } \\
\text { providers }(n=103)\end{array}$ & Questionnaire & $\begin{array}{l}\text { Level of knowledge } \\
\text { and the } \\
\text { self-reported } \\
\text { likelihood to report } \\
\text { elder abuse }\end{array}$ & $\begin{array}{l}\text { The analysis revealed that there was a significant increase in } \\
\text { the number of respondents who felt that they had suspected } \\
\text { elder abuse at least once in their career after the intervention. } \\
\text { There was a significant improvement in self-reported levels of } \\
\text { knowledge. Similarly, knowledge of the reporting process for } \\
\text { elder abuse and neglect was improved after the intervention. } \\
\text { The self-perceived likelihood to report an incidence of elder } \\
\text { abuse showed increased numbers of respondents who would } \\
\text { probably or definitely report. Increases were noted in comfort } \\
\text { levels with recognizing signs and symptoms of elder abuse } \\
\text { and neglect }\end{array}$ \\
\hline Taylor et al. (2006) & USA & Descriptive & $\begin{array}{l}\text { Primary care } \\
\text { physicians }(n=95)\end{array}$ & Questionnaire & $\begin{array}{l}\text { Knowledge deficits } \\
\text { and perceived } \\
\text { barriers to } \\
\text { physician reporting }\end{array}$ & $\begin{array}{l}\text { The majority of respondents recognised that physicians were } \\
\text { not routinely screening for abuse, abuse was overlooked and } \\
\text { that physicians were not familiar with signs of family violence. } \\
\text { Regarding the impact of abuse, most participants expressed an } \\
\text { understanding of the significance of the problem. With respect } \\
\text { to an assessment of barriers to physician reporting, the lack of } \\
\text { understanding about reporting procedures was deemed the } \\
\text { most significant obstacle. There was strong agreement } \\
\text { regarding the need for added education of clinicians. } \\
\text { A majority of the responding physicians did not have a correct } \\
\text { understanding of either prevalence or risk }\end{array}$ \\
\hline
\end{tabular}


Table 1

\begin{tabular}{|c|c|c|c|c|c|c|}
\hline $\begin{array}{l}\text { Authors and } \\
\text { publication date }\end{array}$ & Country & Type of study & Sample & $\begin{array}{l}\text { Information } \\
\text { gathering } \\
\text { techniques }\end{array}$ & Analysed variables & Main results \\
\hline Teresi et al. (2013) & USA & $\begin{array}{l}\text { Randomised } \\
\text { controlled trial }\end{array}$ & $\begin{array}{l}\text { Residents and } \\
\text { professionals of } \\
\text { nursing home units } \\
(n=1405)\end{array}$ & $\begin{array}{l}\text { Questionnaire, } \\
\text { interview and } \\
\text { sheet report }\end{array}$ & $\begin{array}{l}\text { Knowledge, } \\
\text { recognition and } \\
\text { reporting of } \\
\text { resident-to- } \\
\text { resident elder } \\
\text { mistreatment } \\
\text { (R-REM) }\end{array}$ & $\begin{array}{l}\text { There was a significant gain in staff knowledge after training. } \\
\text { Higher levels of recognition and documentation of R-REM } \\
\text { were observed in the experimental as contrasted with the } \\
\text { control group. The results showed that over time the } \\
\text { experimental group reported significantly more R-REM events } \\
\text { than did the control group }\end{array}$ \\
\hline Yaffe et al. (2007) & Canada & Descriptive & $\begin{array}{l}\text { Elderly individuals } \\
(n=858)\end{array}$ & Questionnaire & $\begin{array}{l}\text { Gender and } \\
\text { suspicion of elder } \\
\text { abuse }\end{array}$ & $\begin{array}{l}\text { While the prevalence of elder abuse is estimated to range from } \\
12.0 \% \text { to } 13.3 \% \text {, the specific prevalence was found for females } \\
\text { to be } 13.6-15.2 \% \text { and for males } 9.1-9.7 \%\end{array}$ \\
\hline Yaffe et al. (2009) & Canada & Descriptive & $\begin{array}{l}\text { Family physicians, } \\
\text { nurses and social } \\
\text { workers }(n=31)\end{array}$ & Focus groups & $\begin{array}{l}\text { Professionals' } \\
\text { perspectives } \\
\text { on elder abuse } \\
\text { detection }\end{array}$ & $\begin{array}{l}\text { Individuals from all three disciplines tended to focus on } \\
\text { seniors who were } 80 \text { or older and often frail, frequently } \\
\text { omitting consideration of younger, more active seniors. All } \\
\text { three professions spoke of the desirability of minimising } \\
\text { length of questions, but the reasons for this differed. The social } \\
\text { workers' approach appeared based on need to advocate for } \\
\text { clients. Nurses' viewpoints seemed influenced by utilitarian } \\
\text { concerns for practicality and directness, desire to respect } \\
\text { doctors' time constraints, and discomfort that some } \\
\text { physicians' questioning might impose on nursing fields of } \\
\text { interest. Physicians' concerns tended to be holistic, tempered } \\
\text { by practicality and time management issues. The social } \\
\text { workers felt risk factors must be included in questionnaire } \\
\text { items, however physicians did not. When participants were } \\
\text { asked to rank the top five questions they considered best } \\
\text { overall to meet the goals of an elder abuse suspicion index, the } \\
\text { same five were chosen by all participants and all professions } \\
\text { (though not necessarily in the same rank order) }\end{array}$ \\
\hline Zanza et al. (2004) & Spain & Descriptive & Nurses $(n=47)$ & Questionnaire & $\begin{array}{l}\text { Use of physical } \\
\text { restrictions }\end{array}$ & $\begin{array}{l}\text { The use of physical restraints in geriatric centres appeared } \\
\text { to be a fairly common practice, but it was not identified by } \\
\text { professionals as being a possible abusive action. The } \\
\text { infrastructure and resources of the institutions, dementia, and } \\
\text { the unawareness of the problem among professionals were } \\
\text { considered important risk factors }\end{array}$ \\
\hline
\end{tabular}


Table 2

Characteristics of the studies reviewed (relative frequency).

\begin{tabular}{ll}
\hline Type of study & \\
Theoretical essays & $15.79 \%$ \\
Systematic reviews & $3.51 \%$ \\
Primary investigations & $80.70 \%$ \\
Descriptive & $77.19 \%$ \\
Randomised controlled trial & $3.51 \%$ \\
Country & \\
United States of America & $16 \%$ \\
Australia/Israel/United Kingdom & $8.69 \%$ \\
Spain/Canada & $6.52 \%$ \\
Norway/Ireland & $4.35 \%$ \\
Czech Republic/Romania/Japan/South Korea/Turkey & $2.17 \%$ \\
Sweden and Japan/Norway and Australia & $2.17 \%$ \\
Austria, Belgium, Bulgaria, Germany, Portugal and Slovenia & $2.17 \%$ \\
Information gathering techniques & \\
Questionnaire & \\
Interview & $60.87 \%$ \\
Focus groups & $13.04 \%$ \\
Other techniques & \\
More than one technique &
\end{tabular}

a Analysis of complaints about employees, Delphi panel, research-to-practice consensus workshops.

b Interview and focus groups; questionnaire and interview; questionnaire, interview and focus groups; questionnaire, interview and sheet report.

\section{The influence of definitions used by professionals in the detection} and reporting of cases

Although clinicians often recognise elder abuse, a large percentage reported not having been in contact with a possible victim in the last 12 months (Rinker, 2009). A first aspect that reviewed publications highlight is the need to improve the definitions and classifications of abuse used by professionals (Pillemer et al., 2011). Our review included studies that evaluated the definitions and indicators used by adult protective services professionals (Daly \& Jogerst, 2005), and studies concerning abuse detection by primary care professionals (Coma et al., 2007; Kennedy, 2005; Schmeidel, Daly, Rosenbaum, Schmuch, \& Jogerst, 2012; Taylor, Bachuwa, Evans, \& Jackson-Johnson, 2006). To promote the detection and reporting of possible cases of domestic abuse, practitioners must agree on and use operational definitions to guide their interpretations of available information. Furthermore, some studies (Dyer et al., 2005) showed that the type of professional activity or established relationship with the elder affected the access to information on which professionals could base their decisions. Thus, collaboration between professionals is also crucial to compile a more reliable and comprehensive list of possible indicators. Besides, differences were found between what seniors, family caregivers, and health professionals considered to be abuse (Hempton et al., 2010).

The definitions of institutional abuse and their types have also been studied. The use of physical restraints in geriatric centres appears to be a fairly common practice, according to one of the analysed studies (Zanza et al., 2004), but was not identified by professionals as being a possible abusive action, despite the frequency with which it occurs (Cooper, Dow, Hay, Livingston, \& Livingston, 2013). The term "institutional abuse" can be used to refer to contexts involved in the abuse, and, in most cases, actions or omissions on the part of professionals or family members involved with the patient. Publications that considered abuse among residents in elder care institutions were less frequent (Ellis et al., 2014; Teresi et al., 2013). This type of abuse is often ignored by nurses, and can remain undetected to the extent that it can even be considered normal.

One of the studies reviewed (Bužgová \& Ivanová, 2009) found that employees of residential homes and residents reported all types of abuse identified by WHO, except for sexual abuse, but more often they perceived violations of a patient's rights. Other studies analysed how professionals themselves defined abuse (Hirst, 2002: Sociedad Española de Geriatría y Gerontología, 2004). These studies showed that when social and health professionals were asked to define abuse, their views could be different from that reflected in definitions not generated by the professionals themselves. These results have important implications for the detection and reporting of abuse, and question the usefulness of the statutory definitions if they differ from those used by professionals. The results of other studies also suggest that definitions are influenced by cultural factors, and by job stressors that increase the probability that the abuse is rationalised (Cohen \& Shinan-Altman, 2011; Shinan-Altman \& Cohen, 2009).

\section{The ability of knowledge and attitudes of professionals to act as barriers or facilitators of detection and reporting}

Most of the reviewed articles addressed the barriers and difficulties for professionals to detect and report abuse cases. The following barriers were found: lack of confidence in defining, identifying, and reporting abuse; reluctance to report abuse unless there is certainty that abuse had occurred; concern for the therapeutic relationship; potential consequences for the victim; the risk of a long judicial process; empathy with the abuser; a lack of screening procedures; not having clear definitions of abuse; shortages of available interventions for the abused and abusers; perceptions regarding the intent of the perpetrator; a lack of training; a lack of time; the victim's health; inability or unwillingness of victims to report their situation; absence of clear legislation; ignorance of laws concerning abuse; not knowing where or how to report; a lack of protocols; ethical dilemmas and paradoxes posed by reporting; the belief that abuse is a private family matter; and insecurity about whether the informant will be protected (All, 1994; Almogue et al., 2010; Bover, Moreno, Mota, \& Taltavull, 2003; Cooper et al., 2009; Daly \& Coffey, 2010; Daly, Schmeidel, \& Jogerst, 2012; Joubert \& Posenelli, 2009; Kennelly, Sweeney, \& O’Neill, 2007; Kennedy, 2005; Killick \& Taylor, 2009; Ko \& Koh, 2012; Leddy, Farrow, \& Schulkin, 2014; Liao, Jayawardena, Bufalini, \& Wiglesworth, 2009; Mandiracioglu, Govsa, Celikli, \& Yildirim, 2006; Rodriguez, Wallace, Woolf, \& Mangione, 2006; Schmeidel et al., 2012; Strümpel \& Hackl, 2011; Taylor et al., 2006). Two of the studies reviewed (Schmeidel et al., 2012; Yaffe et al., 2009) showed how perceptions of such barriers to detecting and reporting can vary depending on the professional profile and that health and social services professionals could have different attitudes, beliefs, values, and behaviours towards abuse. For example, compared to the more pragmatic approaches of doctors and nurses to abuse detection, the traditions of social work might encourage an approach based more on abuse defence.

The results regarding the role of professional experience seem to be a source of controversy. The results of some studies showed that health professionals recognised fewer abusive situations than did students in training (Dow et al., 2013); that lower degrees of professional experience predicted greater recognition of abuse (Caciula, Livingston, Caciula, \& Cooper, 2010) and willingness to report abuse (Ko \& Koh, 2012). These findings suggest that, over time, professionals can change their perceptions of what action strategies are acceptable in difficult situations in which there are few available alternatives and then adjust their views according to their level of experience. These results could also be due to the possibility that professionals with more years of work experience find reporting not to be useful. Alternatively, these results could indicate that better training of young professionals increased the likelihood of recognizing abuse. However, we also found other studies indicating that years of professional experience and knowledge regarding the assessment of abuse indicators were predictors of appropriate measures being taken to address cases of suspected abuse, since 
experience could influence the decision-making process (MeeksSjostrom, 2013).

There were other variables that increased the likelihood that abuse could be detected and reported: asking people about abuse; having a reporting protocol; working in a rural community; training to provide information about screening instruments, legislation, and available resources for elder abuse victims; the use of simple detection and reporting mechanisms; and the existence of a single entity that addresses reports of suspected abuse (Cooper et al., 2009; Leddy et al., 2014).

Along with research that focused on analysing the barriers to and facilitators of detecting and reporting abuse, other studies focused on factors that can influence whether professionals diagnose abuse and diagnostic decision making (Killick \& Taylor, 2009; McCreadie et al., 2000; Yaffe, Weiss, Wolfson, \& Lithwick, 2007). The data provided by McCreadie et al. (2000) supported the proposal that the knowledge of risk and, therefore, a greater understanding of the psychosocial circumstances of patients, facilitated the diagnosis of abuse among general practitioners. The systematic review conducted by Killick and Taylor (2009) aimed to identify research on how the decision making of professionals was involved in detecting elder abuse and to extract the key messages that guide their practices. As in other studies, the factors identified in this research were grouped into three categories: (1) case factors related to the client, the caregiver, or context; (2) professional factors related to the professionals or their roles; and (3) institutional factors such as services provided and relevant policies. The results indicated that factors relating to the case, particularly levels of risk and vulnerability, had a major impact on decisions about abuse detection and reporting. Patient age, gender, and health status were considered to be key indicators of vulnerability, while risk components were not clearly identified. Surprisingly, the type and severity of abuse, although important, were discussed in very few studies.

A barrier that seems particularly relevant for reporting institutional abuse was discussed in several of the studies reviewed (Ahern \& McDonald, 2002; Davis \& Konishi, 2007; Granville, 2001; Malmedal, Hammervold, \& Britt-Inger, 2009) and concerns attitudes towards reporting on actions committed by other professionals. Although ethical codes for nurses establish their roles as defenders of patients and force nurses to act when the rights or safety of patients are at risk, reporting wrongdoing or incompetence can place nurses in direct conflict with their fellow professionals, which poses an ethical dilemma. In addition, fear of retaliation by colleagues or supervisors of nurses can present a major barrier to reporting (McCool, Jogerst, Daly, \& Xu, 2009). However, the severity of the damage caused by abuse, the intent, and the belief that reporting is useful, all encourage the reporting of malpractice involving abuse. Also, the belief systems of professionals appear to influence behaviour.

\section{The influence of knowledge and attitudes of professionals} in strategies of action to respond to suspected abuse

One of the reviewed articles (Bomba, 2006) described the use of the Principles of Assessment and Management of Elder Abuse Tool. Such a tool can help maintain an index of suspicion for professionals, which is an essential attitude for detecting cases of suspected abuse. Four publications (Erlingsson, Ono, Sasaki, \& Saveman, 2012; Sandmoe \& Kirkevold, 2013; Sandmoe, Kirkevold, \& Ballantyne, 2011; Strümpel \& Hackl, 2011) considered the strategies of professionals who are faced with a possible case of abuse and found that knowledge and attitudes can affect the way in which they approach situations of suspected abuse.

Strümpel and Hackl (2011) outlined strategies that emerged from interviews with professionals from several European countries on how they addressed domestic violence against older women. Not all organisations have established standard operating procedures, leaving many frontline workers unsure about how to behave and what to do in situations in which abuse might be occurring. Regarding the education of staff and the organisational policy, most social service organisations did not feel adequately prepared.

Erlingsson et al. (2012) compared the actions proposed by Swedish and Japanese nurses regarding hypothetical cases of abuse. Community nurses in Sweden in these situations felt alone, with few resources and with an expectation of competition with other professionals. These nurses felt that their responsibility was to identify and describe the facts, and they expected the doctor to write a report. Meanwhile, Japanese nurses highlighted the need for a collaborative approach that involved the family, other professionals, and the community. They worked on multiple levels, including substantial social networking that fostered interactions not only with family members but also with community and government agencies. Moreover, the nurses felt that they should be present throughout the investigation process. Despite these cultural differences, this study identified common elements and emphasised the possibility of developing generalised instruments and interventions for detecting abuse.

Other research found many similarities in abuse-related difficulties reported by nurses in Australia and Norway and in the actions they performed in response to suspected abuse (Sandmoe et al., 2011). Their performance was influenced by several factors, but the most important were the gravity of the case and the cognitive ability of the victim. The main difficulties reported by nurses were that interventions should be individualised, and they had conflicting feelings about being both responsible for coordinating the activities of victim support and being involved in activities that the client could not fully understand, and the need to establish the boundary between respecting the will of the client and abandonment when a client rejected an intervention These results are consistent with another study analysing the perspectives of nursing team supervisors (Sandmoe \& Kirkevold, 2013). In both studies, the need of frontline professionals for support and guidance from their superiors within the organisation was emphasised, as was the necessity for the organisation to receive the support of other organisations that specialise in intervention services programmes to protect against abuse.

Training as a means to improve the competence of professionals to detect and report elder abuse

Most of the articles included in this review indicated the importance of training for professionals to promote the detection and reporting of elder abuse, and such training can influence the knowledge and attitudes of professionals. This training should be a part of the curriculum for undergraduate, graduate, and continuing education programmes (Starr, 2010). Some papers provided information to identify, prevent, and report abuse (Conry, 2009; Halphen, Varas, \& Sadowsky, 2009). Others (Pillemer et al., 2011) emphasised the need to develop evidence-based training methods and to assess whether such training improves the effectiveness of professionals in identifying abuse, assisting victims, and improving case investigations. One of the systematic reviews included in this review (Cooper et al., 2009) concluded that no study has investigated how rates of detection and reporting could be increased, but did suggest a relationship between whether professionals received training and a higher likelihood of reporting suspected abuse. The analysis of the existing evidence (Bond, 2004; Cooper, Huzzey, \& Livingston, 2012; Dow et al., 2013; Gironda et al., 2010; Shefet et al., 2007; Strümpel \& Hackl, 2011; Sugita \& Garrett, 2012) indicates some features that training programmes on detection and reporting of elder abuse should include: clear procedures regarding how to act and how to report abuse are in place before training courses are 
conducted; to include information about the ageing process to allow contextualisation of abuse cases; adaptation of content to existing regulations; training tailored to the characteristics and needs of the participants; the consideration of the importance of cultural aspects; flexible planning that suits the schedules of the participants and offers a number of appropriate training times to achieve the desired level of learning; the inclusion of different professional profiles, as well as volunteers, to enhance the training experience and provide a foundation for networking between individuals from different professions; the discussion of cases encountered in daily work to facilitate learning; to favour professionals asking seniors about abuse and addressing professionals' concerns about the impact of reporting abuse on their therapeutic relationship with victims and the legal consequences for informants; and the use of standardised patients as the one methodology that can facilitate acquisition of relevant skills.

Three of the reviewed articles described programmes that focused on evaluating the effectiveness of training professionals to address institutional abuse. The most notable results include that professionals increased their knowledge but did not change their attitudes towards older people with dementia; the presence of a ceiling effect in the training, wherein professionals who began the training with a higher level of knowledge learned less (Richardson et al., 2002); the importance of adopting a people-centred perspective; and to conform interventions to the characteristics of each residential centre (Ellis et al., 2014; Teresi et al., 2013).

\section{Discussion}

The results of the studies included in this review indicate the importance of the knowledge and attitudes of health workers as they relate to detection and reporting of abusive situations. The quality of abuse definitions, the accuracy of health professionals' knowledge, and their expectations about the consequences of reporting or how they define their professional role can all influence the actions of health professionals and represent barriers or facilitators to detecting and reporting possible abuse cases. However, other factors can influence the decisions and actions taken by health professionals who encounter elder abuse. Thus, variables related to potential abuse victims and the organisational environment must be considered. Regarding organisational structures, studies included in this review emphasise the importance of having clear procedures to respond to suspected abuse and collaboration between professionals and between organisations or community services. The creation of action guidelines must allow an individualised approach for any case of suspected abuse (Sandmoe et al., 2011; Sandmoe \& Kirkevold, 2013). Such guidance and direction should serve to enhance the activities of frontline professionals and organisations, as well as to encourage interdisciplinary assessment and design of responses to cases of abuse.

Most studies in this review point to training as a means to enhance health professionals' knowledge of abuse detection and reporting rules and procedures. Although most studies found positive effects of training on the knowledge and attitudes of health professionals, there is still little available empirical evidence on the effectiveness of such training in terms of increasing the likelihood that cases will be detected and reported (Pillemer et al., 2011). Moreover, training should not only serve to increase the knowledge of professionals about abuse, but also change their attitudes towards the reporting of suspected cases. Even when they are provided with knowledge and appropriate procedures, professionals can choose not to report a case if they are unsure about whether reporting will benefit families or would cause professional harm. In the absence of such reassurance, only the most serious cases are likely to be reported based on the availability of definitive evidence, while suspected cases may go unreported. Therefore, the effectiveness of training to change attitudes to favour intervention in cases of abuse will be conditioned by other variables such as the type of resources available to assist families and to support health professionals who submit reports. The ethical dilemmas faced by professionals who decide to report cases of suspected domestic or institutional abuse are relevant, and experience can cause some professionals to think that such reporting is not worthwhile.

These concerns highlight the need for continued study of decision-making processes and strategies of professionals who encounter elder abuse. Most of the articles reviewed here collected results and conclusions from studies that explored the attitudes, beliefs, and knowledge of professionals and their relationships with the decisions and actions taken in response to suspected abuse. These investigations should be used as a foundation for pilot studies of theoretical models about the decision-making process involved in detection and reporting. Such models should also include the different variables that were previously shown to influence abuse detection and reporting.

There are two limitations to this review. The first relates to the fact that the studies analysed were found in the selected databases and met the inclusion and exclusion criteria employed. Therefore, studies in other databases, articles written in languages other than English and Spanish, and other types of publications (e.g., books and dissertations) may have been omitted from the analysis. The second limitation relates to the impossibility of accomplishing all the methodological recommendations proposed by some authors (Levac, Colquhoun, \& O’Brien, 2010).

\section{Conflict of interest}

The authors have no conflict of interest to declare.

\section{References}

Ahern, K., \& McDonald, S. (2002). The beliefs of nurses who were involved in a whistleblowing event. Journal of Advanced Nursing, 38, 303-309.

All, A. (1994). A literature review: Assessment and intervention in elder abuse. Journal of Gerontological Nursing, 20, 25-32.

Almogue, A., Weiss, A., Marcus, E.-L., \& Beloosesky, Y. (2010). Attitudes and knowledge of medical and nursing staff toward elder abuse. Archives of Gerontology and Geriatrics, 51, 86-91.

American Psychological Association. (2012). Elder abuse and neglect: In search of solutions. Washington, DC: Author. Available from: http://www.apa.org/pi/aging/ resources/guides/elder-abuse.pdf

Arksey, H., \& O'Malley, L. (2005). Scoping studies: Towards a methodological framework. International Journal of Social Research Methodology, 8(1), 19-32. Retrieved from http://eprints.whiterose.ac.uk/1618/1/Scopingstudies.pdf

Armstrong, R., Hall, B. J., Doyle, J., \& Waters, E. (2011). Cochrane update. 'Scoping the scope' of a Cochrane review. Journal of Public Health, 33, 147-150.

Bomba, P. A. (2006). Use of a single page elder abuse assessment and management tool. Journal of Gerontological Social Work, 46, 103-122.

Bond, C. (2004). Education and a multi-agency approach are key to addressing elder abuse. Professional Nurse, 20, 39-41.

Bover, A., Moreno, M. L., Mota, S., \& Taltavull, J. M. (2003). El maltrato a los ancianos en el domicilio. Situación actual y posibles estrategias de intervención [Elder abuse in the home. The present situation and possible intervention strategies]. Atención Primaria, 32, 1-14

Bužgová, R., \& Ivanová, K. (2009). Elder abuse and mistreatment in residential settings. Nursing Ethics, 16, 110-126.

Caciula, I., Livingston, G., Caciula, R., \& Cooper, C. (2010). Recognition of elder abuse by home care workers and older people in Romania. International Psychogeriatrics, 22, 403-408.

Clark-Daniels, C. L., Daniels, R. S., \& Baumhover, L. A. (1990). Physicians' and nurses' responses to abuse of the elderly: A comparative study of two surveys in Alabama. Journal of Elder Abuse E Neglect, 1, 57-72.

Cohen, M., \& Shinan-Altman, S. (2011). A cross-cultural study of nursing aides attitudes to elder abuse in nursing homes. International Psychogeriatrics, 23, $1213-1221$

Coma, M., Muñoz, J., Postigo, P., Ayuso, M., Sierra, C., \& Sayrol, T. (2007). Visión del maltrato al anciano desde atención primaria [Primary care doctors' and nurses' opinion of elder abuse and neglect]. Gaceta Sanitaria, 21, 235-241.

Conry, M. (2009). Identifying, preventing, and reporting elder abuse. Consultant Pharmacist, 24, 306-315. 
Cooper, C., Dow, B., Hay, S., Livingston, D., \& Livingston, G. (2013). Care workers' abusive behavior to residents in care homes: A qualitative study of types of abuse, barriers, and facilitators to good care and development of an instrument for reporting of abuse anonymously. International Psychogeriatrics, 25, 733-741

Cooper, C., Huzzey, L., \& Livingston, G. (2012). The effect of an educational intervention on junior doctors' knowledge and practice in detecting and managing elder abuse. International Psychogeriatrics, 24, 1447-1453.

Cooper, C., Selwood, A., \& Livingston, G. (2009). Knowledge, detection, and reporting of abuse by health and social care professionals: A systematic review. American Journal of Geriatric Psychiatry, 17, 826-838.

Daly, J., \& Coffey, A. (2010). Staff perceptions of elder abuse. Nursing Older People, 22, $33-37$.

Daly, J., \& Jogerst, G. (2005). Definitions and indicators of elder abuse: A Delphi survey of APS caseworkers. Journal of Elder Abuse \& Neglect, 17(1), 1-19.

Daly, J. M., Schmeidel, A. N., \& Jogerst, G. J. (2012). Critical care nurses' perspectives on elder abuse. Nursing in Critical Care, 17(4), 172-179.

Davis, A. J., \& Konishi, E. (2007). Whistleblowing in Japan. Nursing Ethics, 14(2), $194-202$.

Dong, X. Q. (2015). Elder abuse: Systematic review and implications for practice. Journal of the American Geriatrics Society, 63, 1214-1238.

Dow, B., Hempton, C., Cortes-Simonet, E. N., Ellis, K. A., Koch, S. H., Logiudice, D., et al. (2013). Health professionals' and students' perceptions of elder abuse. Australasian Journal on Ageing, 32(1), 48-51.

Dyer, C., Toronjo, C., Cunningham, M., Festa, N., Pavlik, V., Hyman, D., et al. (2005). The key elements of elder neglect: A survey of Adult Protective Service workers. Journal of Elder Abuse \& Neglect, 17, 1-10.

Ellis, J., Teresi, J. A., Ramirez, M., Silver, S., Boratgis, G., Kong, J., et al. (2014). Managing resident to resident elder mistreatment (R-REM) in nursing homes: The SEARCH approach. Journal of Continuing Education in Nursing, 45(3), 112-123.

Erlingsson, C., Ono, M., Sasaki, A., \& Saveman, B. (2012). An international collaborative study comparing Swedish and Japanese nurses' reactions to elder abuse. Journal of Advanced Nursing, 68(1), 56-68.

Gironda, M. W., Lefever, K., Delagrammatikas, L., Nerenberg, L., Roth, R., Chen, E. A., et al. (2010). Education and training of mandated reporters: Innovative models, overcoming challenges, and lessons learned. Journal of Elder Abuse \& Neglect, 22, 340-364.

Granville, K. (2001). Perceptions of intentional wrongdoing and peer reporting behavior among registered nurses. Journal of Business Ethics, 34, 1-13.

Halphen, J. M., Varas, G. M., \& Sadowsky, J. M. (2009). Recognizing and reporting elder abuse and neglect. Geriatrics, 64, 13-18.

Hempton, C., Dow, B., Cortes-Simonet, E., Ellis, K., Koch, S., LoGiudice, D., et al. (2010). Contrasting perceptions of health professionals and older people in Australia: What constitutes elder abuse? International Journal of Geriatric Psychiatry, 26, 466-472.

Hirst, S. P. (2002). Defining resident abuse within the culture of long-term care institutions. Clinical Nursing Research, 11, 267-284.

Joubert, J. L., \& Posenelli, S. (2009). Responding to a window of opportunity: The detection and management of aged abuse in an acute and subacute health care setting. Social Work in Health Care, 48, 702-714.

Jones, J. S., Veenstra, T. R., Seamon, J. P., \& Krohmer, J. (1997). Elder mistreatment: National survey of emergency physicians. Annals of Emergency Medicine, 30, 473-479.

Kennedy, R. D. (2005). Elder abuse and neglect: The experience, knowledge, and attitudes of primary care physicians. Family Medicine, 37, 481-485.

Kennelly, S., Sweeney, N., \& O’Neill, D. (2007). Elder abuse: Knowledge, skills, and attitudes of healthcare workers. Irish Medical Journal, 100, 326.

Killick, C., \& Taylor, B. (2009). Professional decision making on elder abuse: Systematic narrative review. Journal of Elder Abuse E Neglect, 21(3), 211-238.

Ko, C., \& Koh, C. K. (2012). Factors related to Korean nurses' willingness to report suspected elder abuse. Asian Nursing Research, 6, 115-119.

Lachs, M. S., \& Pillemer, K. A. (2015). Elder abuse. New England Journal of Medicine, 373, 1947-1956

Levac, D., Colquhoun, H., \& O'Brien, K. K. (2010). Scoping studies: Advancing the methodology. Implementation Science, 5(69). Retrieved from http://www.implementationscience.com/content/pdf/1748-5908-5-69.pdf

Leddy, M. A., Farrow, V. A., \& Schulkin, J. (2014). Obstetrician-gynecologists' knowledge, attitudes, and practice regarding elder abuse screening. Womens Health Issues, 24, 455-464

Liao, S., Jayawardena, K., Bufalini, E., \& Wiglesworth, A. (2009). Elder mistreatment reporting: Differences in the threshold of reporting between hospice and palliative care professionals and adult protective service. Journal of Palliative Medicine, $12,64-69$.

Malmedal, W., Hammervold, R., \& Britt-Inger, S. (2009). To report or not report? Attitudes held by Norwegian nursing home staff on reporting inadequate care carried out by colleagues. Scandinavian Journal of Public Health, 37, 744-750.
Mandiracioglu, A., Govsa, F., Celikli, S., \& Yildirim, G. O. (2006). Emergency health care personnel's knowledge and experience of elder abuse in Izmir. Archives of Gerontology and Geriatrics, 43, 261-267.

McCool, J. J.., Jogerst, G. J., Daly, J. M., \& Xu, Y. (2009). Multidisciplinary reports of nursing home mistreatment. Journal of the American Medical Directors Association, 10(3), 174-180.

McCreadie, C., Bennett, G., Gilthorpe, M. S., Houghton, G., \& Tinker, A. (2000). Elder abuse: Do general practitioners know or care? Journal of the Royal Society of Medicine, 93, 67-71.

Meeks-Sjostrom, D. J. (2013). Clinical decision making of nurses regarding elder abuse. Journal of Elder Abuse \& Neglect, 25, 149-161.

Pillemer, K., Breckman, R., Sweeney, C., Brownell, P., Fulmer, T., Beman, J., et al. (2011). Practitioners' views on elder mistreatment research priorities: Recommendations from a research-to-practice consensus conference. Journal of Elder Abuse \&' Neglect, 23, 115-126.

Richardson, B., Kitchen, G., \& Livingston, G. (2002). The effect of education on knowledge and management of elder abuse: A randomized controlled trial. Age and Ageing, 3, 335-341.

Rinker, A. G. (2009). Recognition and perception of elder abuse by prehospital and hospital-based care providers. Archives of Gerontology and Geriatrics, 48(1), $110-115$.

Rodriguez, M. A., Wallace, S. P., Woolf, N. H., \& Mangione, C. M. (2006). Mandatory reporting of elder abuse: Between a rock and a hard place. Annals of Family Medicine, 4, 403-409.

Sandmoe, A., \& Kirkevold, M. (2013). Identifying and handling abused older clients in community care: The perspectives of nurse managers. International Journal of Older People Nursing, 8, 83-92.

Sandmoe, A., Kirkevold, M., \& Ballantyne, A. (2011). Challenges in handling elder abuse in community care: An exploratory study among nurses and care coordinators in Norway and Australia. Journal of Clinical Nursing, 20, 3351-3363.

Schmeidel, A., Daly, J., Rosenbaum, M., Schmuch, G., \& Jogerst, G. (2012). Health care professionals' perspectives on barriers to elder abuse detection and reporting in primary care settings. Journal of Elder Abuse \& Neglect, 24, 17-36.

Shefet, D., Dascal-Weichhendler, H., Rubin, O., Pessach, N., Itzik, D., Benita, S., et al. (2007). Domestic violence: A national simulation-based educational program to improve physicians' knowledge, skills and detection rates. Medical Teacher, 29(5), 133-138.

Shinan-Altman, S., \& Cohen, M. (2009). Nursing aides' attitudes to elder abuse in nursing homes: The effect of work stressors and burnout. Gerontologist, 49, 674-684.

Sociedad Española de Geriatría y Gerontología. (2004). La percepción de los profesionales sobre negligencia, abuso y maltrato a las personas mayors [The perception of professionals on neglect, abuse and mistreatment of the elderly]. Revista Española de Geriatría y Gerontología, 39, 240-254.

Starr, L. (2010). Preparing those caring for older adults to report elder abuse. Journal of Continuing Education in Nursing, 41(5), 231-235.

Strümpel, C., \& Hackl, L. (2011). The Breaking the Taboo projects - Raising awareness of, and training staff in, community health and care services on violence against older women within families. Journal of Adult Protection, 13, 323-335.

Sugita, J., \& Garrett, M. (2012). Elder abuse and oral health care providers: An intervention to increase knowledge and self-perceived likelihood to report. Journal of Elder Abuse \& Neglect, 24, 50-64.

Taylor, D. K., Bachuwa, G., Evans, J., \& Jackson-Johnson, V. (2006). Assessing barriers to the identification of elder abuse and neglect: A communitywide survey of primary care physicians. Journal of the National Medical Association, 98, 403-404

Teresi, J. A., Ramirez, M., Ellis, J., Silver, S., Boratgis, G., Kong, J., et al. (2013) A staff intervention targeting resident-to-resident elder mistreatment (R-REM) in long-term care increased staff knowledge, recognition and reporting: Results from a cluster randomized trial. International Journal of Nursing Studies, 50, 644-656.

World Health Organization. (2002). The Toronto declaration on the global prevention of elder abuse. Geneva: World Health Organization. Retrieved from http:// www.who.int/ageing/projects/elder_abuse/alc_toronto_declaration_en.pdf

World Health Organization. (2011). European report on preventing elder maltreatment. Roma: World Health Organization. Retrieved from http://www.euro.who.int/__data/assets/pdf_file/0010/144676/e95110.pdf

Yaffe, M. Weiss, D., Wolfson, C. \& Lithwick, M. (2007). Detection and prevalence of abuse of older males: Perspectives from family practice. Journal of Elder Abuse $\mathcal{E}$ Neglect, 19, 47-60

Yaffe, M., Wolfson, C., \& Lithwick, M. (2009). Professions show different enquiry strategies for elder abuse detection: Implications for training and interprofessional care. Journal of Interprofessional Care, 23, 646-654.

Zanza, M. J., Toronjo, A., Rojas, M. J., Díaz, O., Elsden, C. A., \& Soldevilla, J.J. (2004). Uso de restricciones físicas en las instituciones gerontogeriátricas [Use of physical restrictions in gerontogeriatrics institutions]. Gerokomos. Revista de la Sociedad Española de Enfermería Geriátrica y Gerontológica, 15, 217-227. 